\title{
Distribution and geochemical composition of oil-bearing fluid inclusions compared to crude oil, oil shows and rock extracts in a Campos Basin well, offshore Brazil
}

\author{
Carlos Eduardo Silva Coelho ${ }^{1}$, Simon Christopher George ${ }^{2,3}$, Herbert Volk $^{3}$, Peter John Eadington ${ }^{4}$ \\ \& Andrew Stuart Ross ${ }^{4}$
}

\begin{abstract}
An offshore well containing a shallow, biodegraded producible oil zone underlain by an intermediate oil show zone (slightly biodegraded) and a deep oil show (unbiodegraded). The objective of this study was to screen for the presence of oil-bearing fluid inclusions (FIs), use this information for determining the extent of paleo-oil zones and compare their geochemistry to oils, oil shows and rock extracts. A Grains with Oil Inclusions $\left(\mathrm{GOI}^{\mathrm{TM}}\right)$ value of $5.3 \%$ in the producible oil zone is moderate but FIs are small $(<5 \mu \mathrm{m})$ and rare. Lower GOI values $(0.7-2.0 \%)$ in the intermediate oil show interval are evidence for migration and possibly accumulation of oil. In the deep oil show FIs occur more frequently (GOI $=9.6-19 \%)$, are larger and are more abundant within grains. Their geochemical signature is similar to the oil show in terms of secondary alteration (non-biodegraded), maturity (peak of oil window) and source signature (clay-rich, probably Cretaceous or younger, suboxic marine shales). The inclusion oil does not correlate with the less mature and lacustrine producible oil or the intermediate oil show, nor does it correlates with the significantly less mature marine mudstones in the well. Similar maturities (peak of oil window) are indicated by parameters calculated from a wide boiling range of compounds, so PIs probably trapped oil from a single charge event. Both palaeo- and current oil in the deep oil show interval differ from the upper producible oil and we infer that they were generated from a deeper source and migrated vertically.
\end{abstract}

Keywords: petroleum inclusions, crude oil, grains with oil inclusions, molecular composition, geochemistry.

Resumo Distribuição e composição geoquímica de inclusões fuidas de petróleo comparadas com as do óleo cru, indícios e extratos em um poço submarino na Bacia de Campos, Brasil. Um dado poço offshore contendo uma zona produtora superior de óleo biodegradado sotoposta por uma zona intermediária com indícios de óleo ligeiramente biodegradados e por uma zona profunda com indícios de óleo nãobiodegradados. O objetivo deste estudo foi procurar inclusões fluidas de petróleo (IFs), determinar a extensão de zonas de paleo-óleo e comparar a composição geoquímica dos óleos, indícios de óleo e extratos da rocha. Grãos com inclusões de óleo ( $\left.\mathrm{GOI}^{\mathrm{TM}}\right)$ de $5.3 \%$ na zona produtora de óleo é moderado mas as IFs são pequenas $(<5 \mu \mathrm{m})$. Valores inferiores de GOI $(0,7-2,0 \%)$ no intervalo intermediário são evidências de migração e possivelmente de acumulação de óleo. Na zona profunda as IFs ocorrem mais freqüentemente (GOI =9.6-19\%) e são maiores. Sua assinatura geoquímica é similar ao indício de óleo deste intervalo em termos de alteração secundária (não-biodegradada), maturidade (pico da janela de óleo) e da assinatura da rocha geradora (folhelhos marinhos subóxicos ricos em argila (e pobres em carbonato), de idade provavelmente cretácica ou mais jovem). O óleo da inclusão não se correlaciona com o óleo produzido (menos maturo e lacustre) ou com os indícios de óleo da zona intermediária e nem com os folhelhos marinhos menos maturos desse poço. As maturidades similares das IFs no pico da janela de óleo indicam que provavelmente esses óleos foram aprisionados nesse único evento de carga. Ambos, paleo- e óleos presentes no intervalo inferior diferem do óleo da zona produtora superior provavelmente foram gerados por uma geradora profunda e migraram verticalmente.

Palavras-chave: Inclusões de petróleo, óleo cru, grãos com inclusões de petróleo, composição molecular, geoquímica.

INTRODUCTION Oil-bearing fluid inclusions (FIs) commonly occur within petroleum reservoirs and along migration pathways. They are tiny droplets (usually $<10 \mu \mathrm{m}$ to $50 \mu \mathrm{m}$ ) of oil encapsulated in defects in mineral grains and diagenetic cements. Therefore, they preserve oil in a closed system in framework minerals such as quartz and feldspar. Consequently the inclusion oil is protected from secondary alteration processes

1 - Petrobras/CENPES/PDEXP/GEOQ, Cid. Universitária, Rio de Janeiro, Brasil. E-mail: cescoelho@petrobras.com.br

2 - Department of Earth and Planetary Sciences, Macquarie University, Sydney, NSW 2109, Australia. E-mail: sgeorge@els.mq.edu.au

3 - CSIRO Petroleum, PO Box 136, North Ryde, NSW 2113, Australia. E-mail: Herbert.Volk@csiro.au

4 - CSIRO Petroleum, PO Box 1130,Bentley, WA 6102,Australia. E-mails: Peter.Eadington@csiro.au, Andrew.Ross@csiro.au 
such as biodegradation, water washing or other postemplacement processes that may free oil after emplacement (e.g., George et al., 2007).

In contrast, the geochemical composition of free petroleum may be the result of a complex charge history, where oils from different source rocks types may have contributed with petroleum charges over a wide spectrum of geological time and maturity. Additionally, petroleum charges of different composition tend to form a homogeneous mixture over geological time (England et al., 1987), making it difficult to reconstruct the charge history of a petroleum reservoir using only the analysis of currently accumulated oils. In order to providing relatively pristine and robust data for source and maturity characteristics of palaeo-oil during the early stages of reservoir charging, fluid inclusion oils may the only fresh oil samples that can be obtained (e.g. Volk et al., 2005), may be the only oil sample left in a now gas-filled structure (George et al., 2004), or may be the only samples of live oils in frontier basins (Volk et al., 2002).

GEOLOGICAL SETTING The Campos basin covers an area of about $100,000 \mathrm{~km}^{2}$ (out to the 3400-m isobath), located offshore from rio de janeiro in southeastern brazil (Fig. 1). The oil fields discovered occur in water depths ranging from $80 \mathrm{~m}$ to more than $2600 \mathrm{~m}$.

Recently, the Campos Basin accounts for more than $80 \%$ of the total exploitable Brazilian reserves and $75 \%$ of total oil production. The Barremian calcareous shales from the Lagoa Feia Formation are the main source rocks of all the petroleum in the basin (Guardado et al., 2000). Accumulations occur in a variety of siliciclastic and carbonate reservoirs, ranging from Barremian to Miocene in age. Upper Cretaceous-Tertiary turbidites contain most of the oil. Peak oil generation occurred during late Miocene time, and the most important migration pathways are through salt windows and along listric faults (Guardado et al., 2000).

ANALYTICAL PROCEDURES AND SAMPLES The analytical methodologies used here, particularly those that were developed and refined at CSIRO (GOI - Grains containing Oil Inclusions (Eadington et al., 1996); and MCI - Molecular Composition of Inclusion (George et al., 2007), are applicable to permit the direct comparison between inclusion oil geochemistry and crude oils.

Prior to geochemical analysis of oil inclusions it is necessary to determine that sufficient and large enough oil inclusions are present for analysis (George et al., 2001). This can be achieved using petrographic methods including GOI using UV light, since fluorescence is used for detecting oil inclusions under the microscope. The abundance of oil inclusions in a particular reservoir section has been used as an indicator to support the presence of paleo oil accumulations (e.g. Lisk \& Eadington, 1994; Oxtoby et al., 1995).
Petrographic methods The location of oil inclusions in relation to fluid inclusion trapping sites was investigated by optical microscopy and cathodoluminescencescanning electron microscopy (SEM-CL). Once oil inclusions were identified, their distribution was determined using the GOI technique, a petrographic method that uses a computer-controlled microscope stepping stage to measure the abundance of quartz and feldspar grains containing oil-bearing fluid inclusions in siliciclastic rock (cuttings or core samples), and relates this parameter to an empirical database of GOI values from known oil fields to determine the extent of oil saturation in the geological past (Eadington et al., 1996; Lisk et al., 2000; Lisk et al., 2002; Liu et al., 2004). Oil accumulation in the geological past (palaeo-oil zones, GOI values $>5 \%$ ) can generally be differentiated from oil on migration pathways (GOI values between 0.1 and $5 \%$ ). If no oil has been present in a reservoir, GOI values are generally $<0.1 \%$.

The studied well contains a shallow (3067/3074 $\mathrm{m})$, biodegraded producible oil $\left(16^{\circ} \mathrm{API}\right)$ zone, underlain by an intermediate oil show $(4880 / 4908 \mathrm{~m})$ that is slightly biodegraded, and a deep oil show $(5360 / 5400 \mathrm{~m})$ that is unbiodegraded. The well penetrated siliciclastic rocks ranging from Paleocene to Albian in age.

A total of twenty-eight cutting samples were collected from the studied well. Four samples are from the reservoir interval with producible oil (3063-3075 $\mathrm{m})$, eleven are from the zone of oil-shows at 4875$4905 \mathrm{~m}$ and thirteen are from the zone of oil-shows at $5355-5400 \mathrm{~m}$. The amount of shale is variable and some samples from the $4878-4893 \mathrm{~m}$ and $5358-5373$ $\mathrm{m}$ intervals are comprised mostly of shale and/or silt. In these samples, a concentrate of quartz and feldspar grains was used to prepare the fluid inclusion thin sections.

Petrographic analysis was carried out on fluid inclusion thick sections, according with the number of samples from each of the reservoir intervals that were investigated. Optical microscopy and SEM-CL were used in combination with optical petrography. Particular attention was paid to documenting the grain size and inclusion locations in terms of host mineral, presence of overgrowths and presence of healed diagenetic fractures.

The grain-size distribution was estimated from measurement of a number of representative grains using transmitted light microscopy, with the maximum grain size measured from the largest cross section of individual grains. Assessment of textural maturity was based on the index proposed by Powers (1953), with the overall average amount of angularity and weathering of grains in the samples estimated by carefully scanning the sample slide using transmitted light microscopy. The extent of sorting, although not based on core samples, used the classification proposed by Pettijohn et al. (1972) and gave an estimate of the sorting characteristics of the lithology encountered at each reservoir interval investigated.

Quartz overgrowths were detected using 
SEM-CL as a rim of low luminescent quartz surrounding a detrital grain with variable, but often bright luminescence. Under CL conditions, quartz precipitated as authigenic cement is non-luminescent and appears black, including quartz cementing fractures in the detrital grain that were healed during diagenesis. The samples were analyzed using a SEM with a CL detector at the Electron Microscopy facility at CSIRO in Perth (Australia). For each sample, nine SEM-CL images per thin section were collected using 150x magnification. The proportion of quartz overgrowths was quantified by superposition of a grid of 54 points over each image, so that a total of 486 points were counted for each sample. The result is a quantitative estimate of the twodimensional area occupied by the quartz overgrowth in the bulk sample.

Microfractures are common features in most sedimentary rocks and occur in a variety of forms that often serve as sites for the trapping of fluid inclusions. Data were collected on the abundance of fractures in each sample to test the relationship between fracture abundance and trapping of oil inclusions. Microfractures are commonly filled with authigenic quartz which is in optical continuity with the detrital quartz under a standard optical microscope. However, CL imaging in a SEM reveals luminescence contrast in detrital, authigenic and fracture-fill quartz. Quartz precipitated from aqueous solution at relatively low temperatures tends to have less intense CL than does quartz crystallized at high temperatures. Fracture shape and arrangement were used to rank fractures into style categories I, II and III, as defined by Laubach (1997), with an additional category IV added to account for fractures of an indeterminate origin.

Geochemical methods The oil trapped within FIs in the quartz or feldspar grains of the sandstones or arkoses was extracted and analysed according to the MCI protocols, a detailed description of which has been provided in George et al., $(1998,2007)$. A pre-requisite for the successful analysis of the tiny amounts of oil trapped in FIs is the complete removal of oil and any other contaminants from the outside of the grains prior to crushing of the rock under solvent to recover the inclusion oil (off-line method). The fluid inclusion oil was analysed by gas chromatography-mass spectrometry (GC-MS) using an AutoSpec Q system (George et al., 1998). Quantification was carried out using single ion monitoring (SIM) and metastable reaction monitoring (MRM).

The RFT $3069.5 \mathrm{~m}$ oil was analysed in the geochemistry labs at Petrobras R\&D Centerby: liquid chromatography, gas chromatography, GC-MS (steranes and terpanes) and by one analysis by MRM GC/MS-MS to verify the presence of $\mathrm{C}_{30}$ steranes

\section{RESULTS}

\section{Petrographic analyses}

OIL ZONE SAMPLE The current oil zone (3066-3069 m) sample is a well sorted sub-arkose comprising approximately $73 \%$ detrital quartz and $25 \%$ feldspar, with minor amounts of authigenic quartz as overgrowth and calcite cement. The grain size is silt to coarse sand. The detrital grains are typically angular to sub-angular and

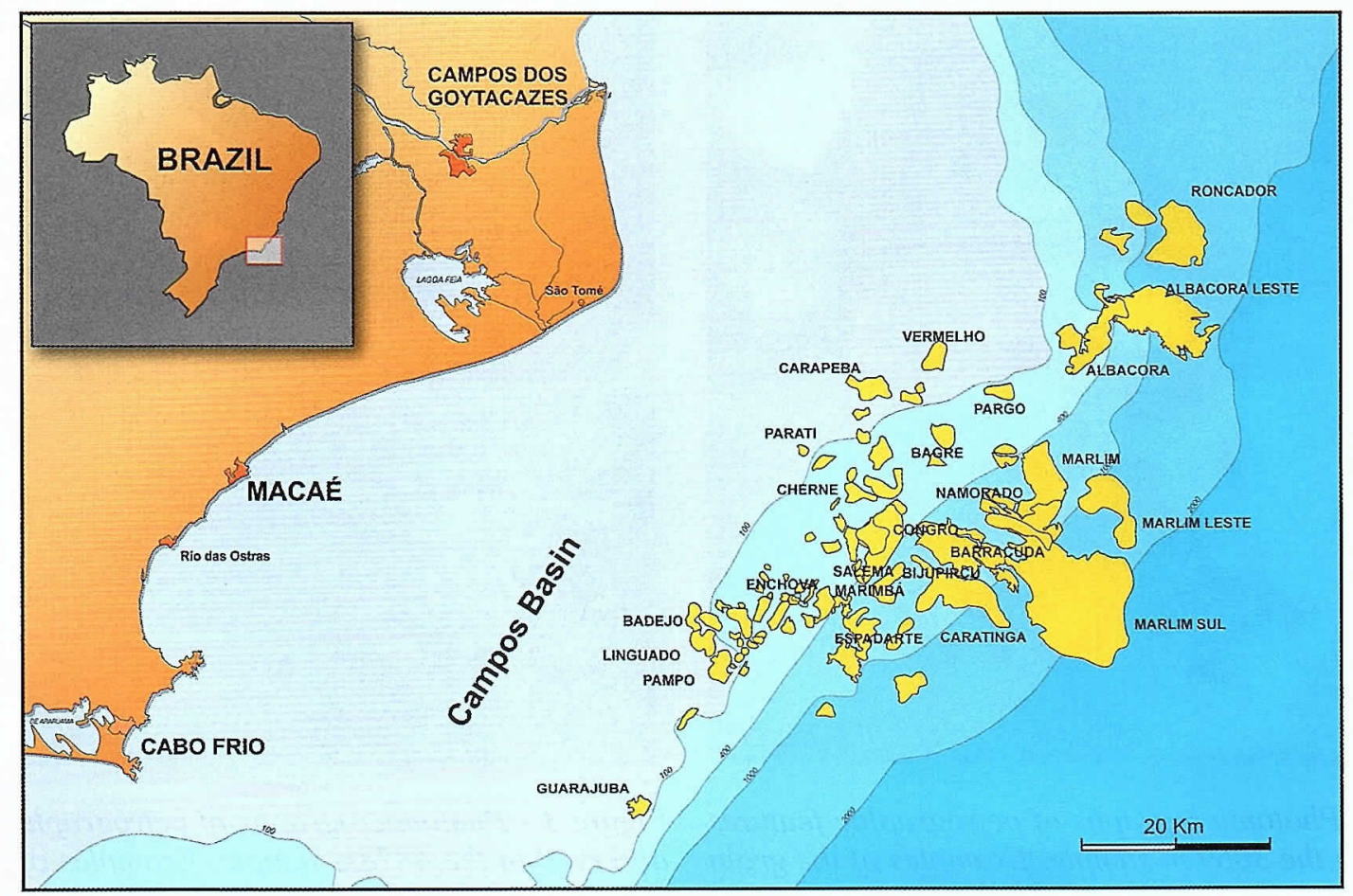

Figure 1 - Location map of the main petroleum fields in the Campos Basin, discovered up to 1997. From Milani et al., 2000. 
the sample is well sorted. Most detrital quartz grains have no overgrowth detected in transmitted light microscopy.

Where developed, the quartz overgrowth occurs as discontinuous rims mainly over quartz grains generally less than $10 \mu \mathrm{m}$ in wide (Fig. 2). The percentage of overgrowth in the sample calculated from SEM-CL observations was $6.8 \%$ and the percentage of fractured grains was $21 \%$. The proportion of feldspar grains is $25 \%$ of which $25 \%$ are heavily altered. Seven percent of quartz grains have overgrowths and $20 \%$ of quartz grains have healed fractures, of which $40 \%$ are healed by diagenetic quartz (Fig. 2).

UPPER OIL SHOW INTERVAL SAMPLE (4878 M) The sample is a sub-arkose, comprised of approximately $60 \%$ detrital quartz, 30\% feldspar and 10\% calcite cement, with minor authigenic quartz as overgrowths. The grain size range was measured to be between $100 \mu \mathrm{m}$ (very fine) and $1100 \mu \mathrm{m}$ (very coarse), with a normal distribution between $200-300 \mu \mathrm{m}$. The detrital grains are typically angular and the sample is moderately sorted. Seventy percent of feldspar grains are altered. Nine percent of quartz grains have over-

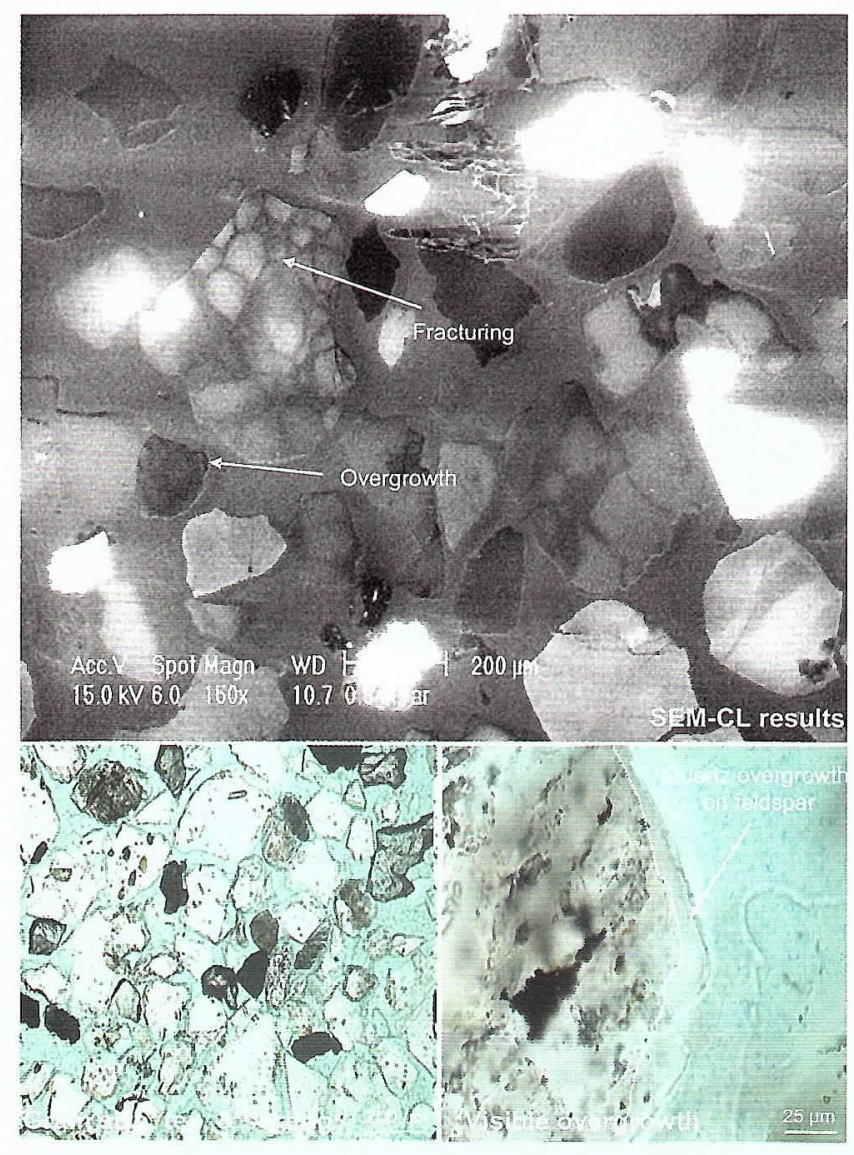

Figure 2 - Photomicrographs of petrographic features observed in the $3069 \mathrm{~m}$ sample. Examples of the grain size, texture, sorting and overgrowth using transmitted light microscopy and examples of the fractures and overgrowth using $S E M-C L$ are shown. growths and $18 \%$ have healed fractures, of which $65 \%$ are healed by diagenetic quartz.

Where present the quartz overgrowth occurs as discontinuous rims less than $10 \mu \mathrm{m}$ in thickness (Fig. 3). The percentage of overgrowths in the sample calculated from SEM-CL observations is $8.4 \%$ and the percentage of fractured grains is $18.0 \%$. The sample is comprised mostly of monocrystalline quartz and feldspar grains, of which approximately $15 \%$ are cemented and aggregated grains. These grains are often welded aggregates of quartz and feldspar, or several small grains of feldspar and quartz with calcite cement (Fig. 3).

LOWER OIL SHOW INTERVAL SAMPLE (5382 M) The sample is an arkose, and is comprised of approximately $47 \%$ detrital quartz and $48 \%$ feldspar (of which $70 \%$ are heavily altered), with minor authigenic quartz as overgrowths and calcite cement (Fig. 4). The grain sizes ranged between $100 \mu \mathrm{m}$ (very fine) and $400 \mu \mathrm{m}$ (medium), with a normal distribution between 150-200 $\mu \mathrm{m}$ (Fig. 4). The detrital grains are typically angular to sub-angular and the sample is moderately well sorted. The distribution of grain size, texture and sorting is illustrated in figure 4. Most detrital quartz grains have no

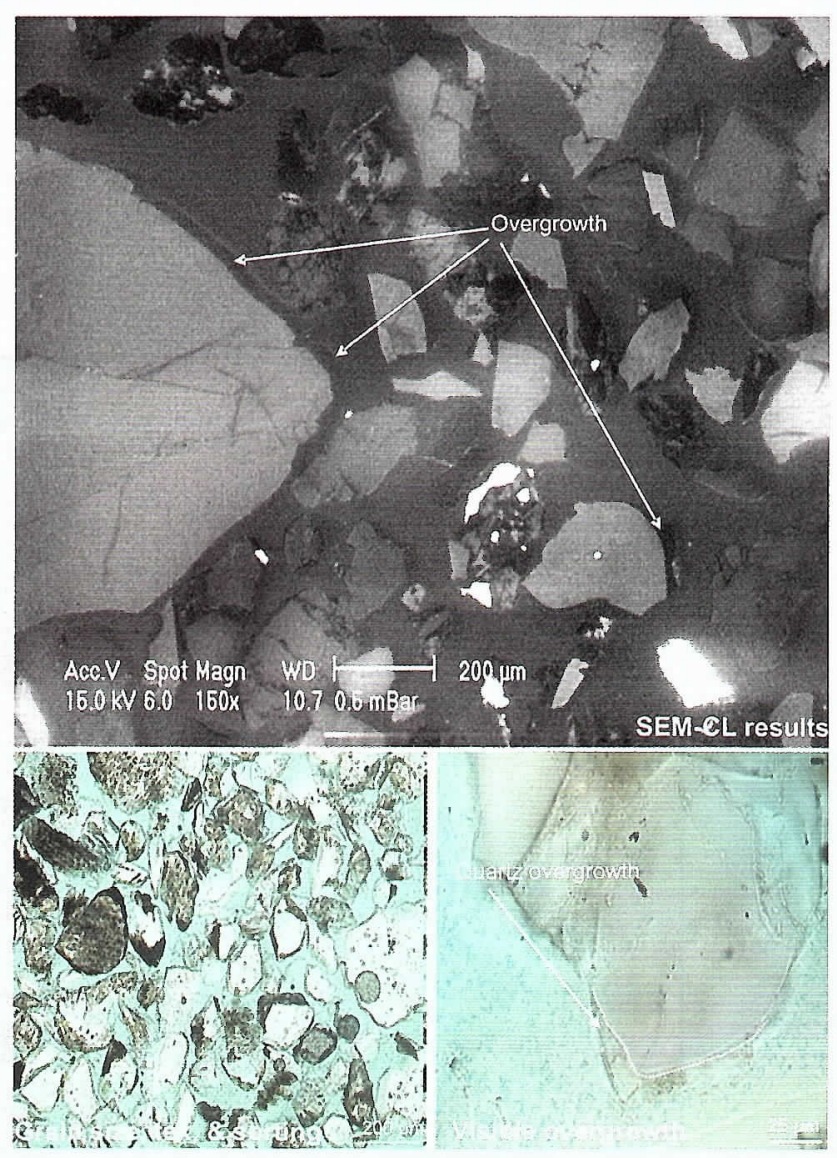

Figure 3 - Photomicrographs of petrographic features observed in the $4878 \mathrm{~m}$ sample. Examples of the grain size, texture, sorting and overgrowth using transmitted light microscopy and an example of the fractures and overgrowth using SEM-CL are shown. 


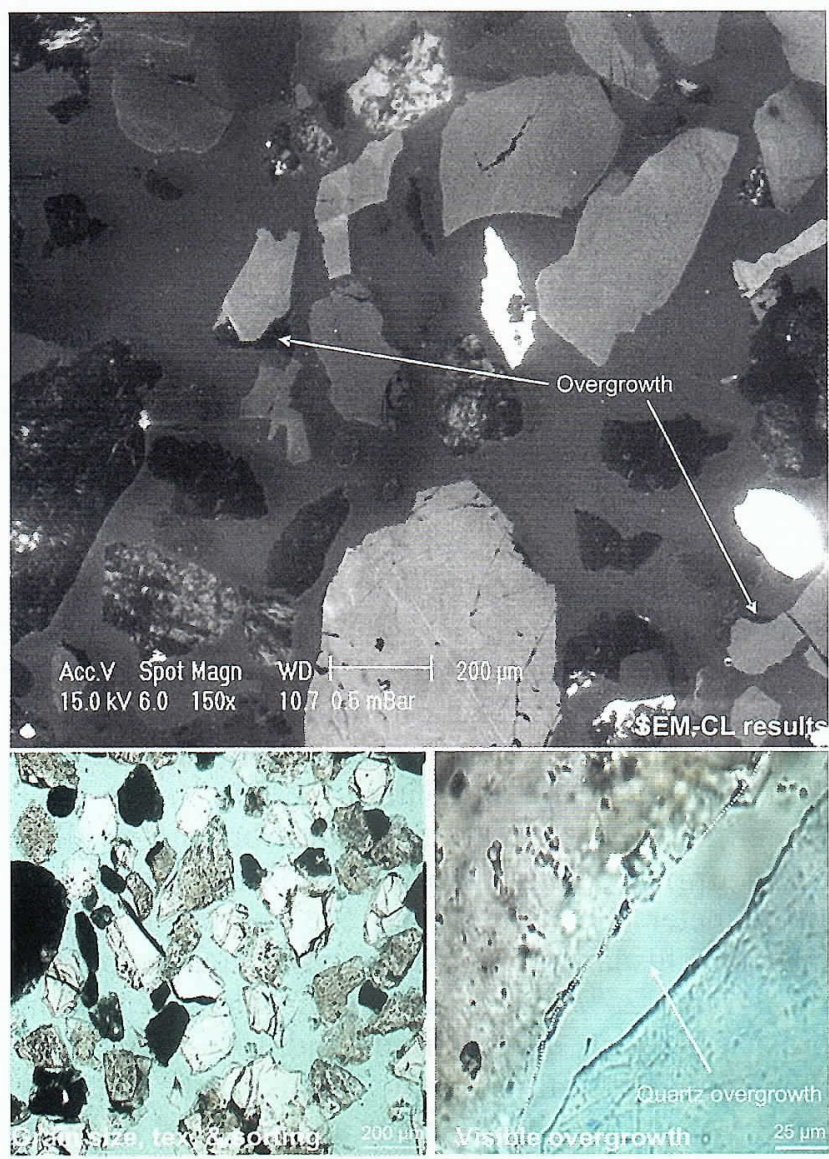

Figure 4 - Photomicrographs of petrographic features observed in the $5382 \mathrm{~m}$ sample. Examples of the grain size, texture, sorting and overgrowth using transmitted light microscopy and an example of the fractures and overgrowth using SEM-CL are shown.

overgrowths detected in transmitted light microscopy (only 3\% have overgrowths). Where present, quartz overgrowths occurs as discontinuous rims less than $10 \mu \mathrm{m}$ in thickness on quartz grains (Fig. 4). Ten percent of quartz grains have healed fractures, of which $50 \%$ are healed by diagenetic quartz. The percentage of overgrowths in the sample calculated from SEM-CL observations is $3.7 \%$ and the percentage of fractured grains is $9.7 \%$. Most grains are monocrystalline and approximately $5 \%$ are in the form of cemented and aggregated grains. These grains are often comprised of welded aggregates of quartz and feldspar, or several small grains of feldspar and quartz encased within calcite cement.

GOI Data The GOI data are presented for three depth intervals; 3063-3075 $\mathrm{m}$ in the current oil zone, 4875-4908 m with oil shows, and 5367-5400 m with oil shows.

OIL ZONE SAMPLES (3063-3075 M) GOI values for samples from the interval are $3.9 \%$ to $5.3 \%$ (Fig. 5). The oil inclusions typically occur in the detrital grains as single, isolated inclusions often less than about $4 \mu \mathrm{m}$ in size (Fig. 6). Oil inclusions with fluorescence colours

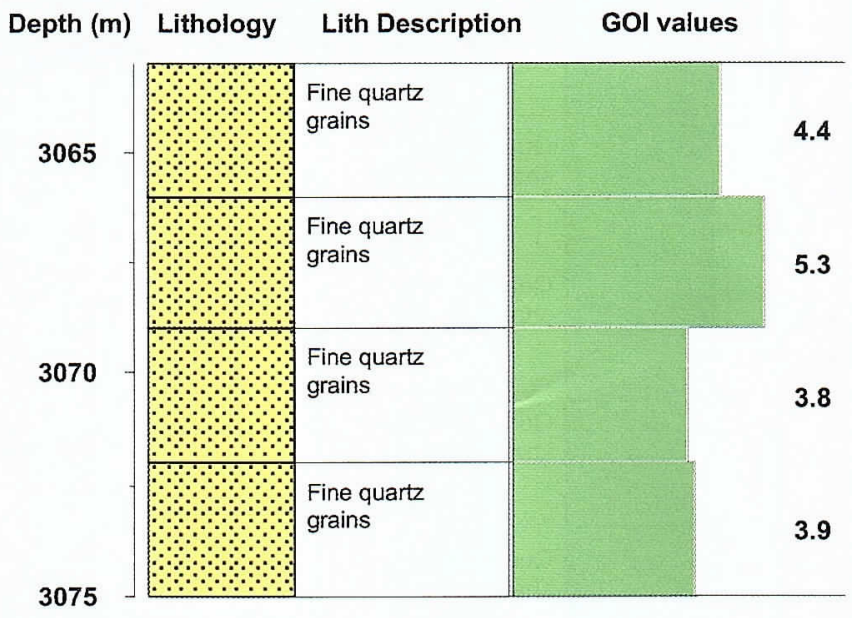

Figure 5 - Lithology and GOI depth logs for the 3063-3075 m interval. The GOI values are plotted as percentages and lithology is based on the description of the cuttings samples.
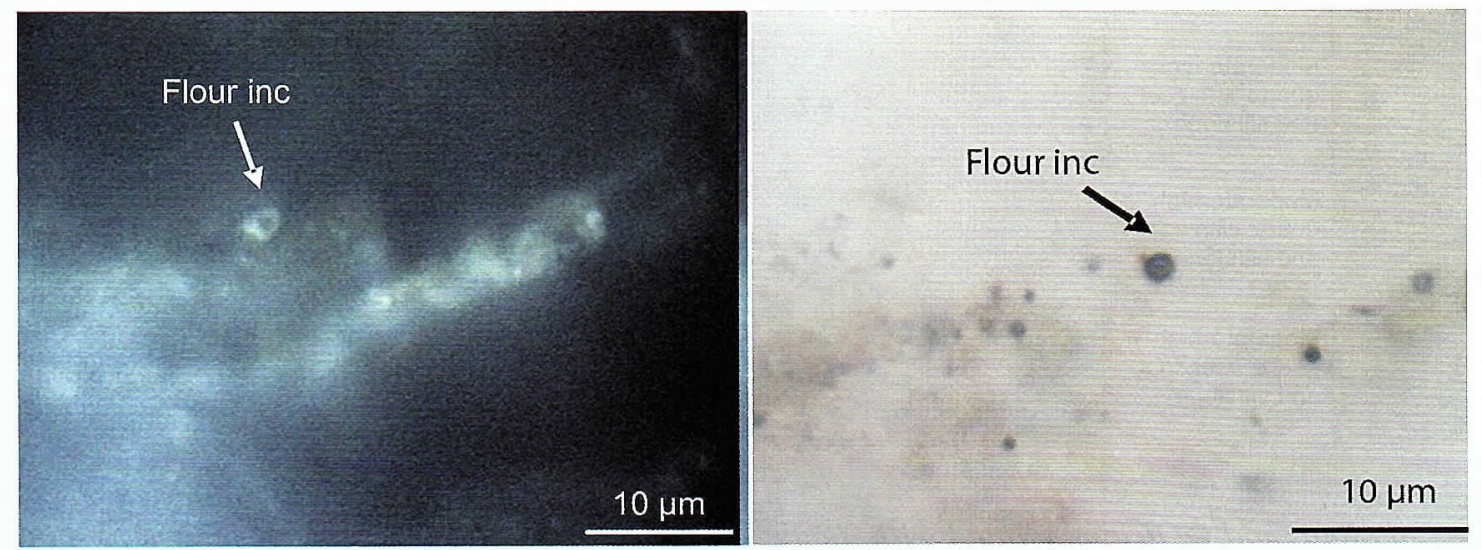

Figure 6 - Photomicrographs showing an oil inclusion from the 3063-3075 m interval under U/V and with transmitted light at $1000 \times$ magnification for one of the oil zone samples. 
of near-blue, near-white, and yellow-orange occur in similar numbers. About $80 \%$ of the oil inclusions are located in healed fractures within detrital quartz, and about $20 \%$ of the oil inclusions are in feldspar associated with altered domains of the grains. In the $3066 \mathrm{~m}$ and $3075 \mathrm{~m}$ samples some oil inclusions occur at the quartz overgrowth boundary. No inclusions were observed within the overgrowth rim.

UPPER OIL SHOW INTERVAL SAMPLES (4875 TO $4908 \mathrm{M}$ ) GOI results for samples from this interval are $0.7 \%$ to $2 \%$ (Fig. 7). Grains contain single, small inclusions, often less than about $4 \mu \mathrm{m}$ (Fig. 8). The fluorescence colours of the oil inclusions include near-blue, near-white and yellow-orange, which is comparable

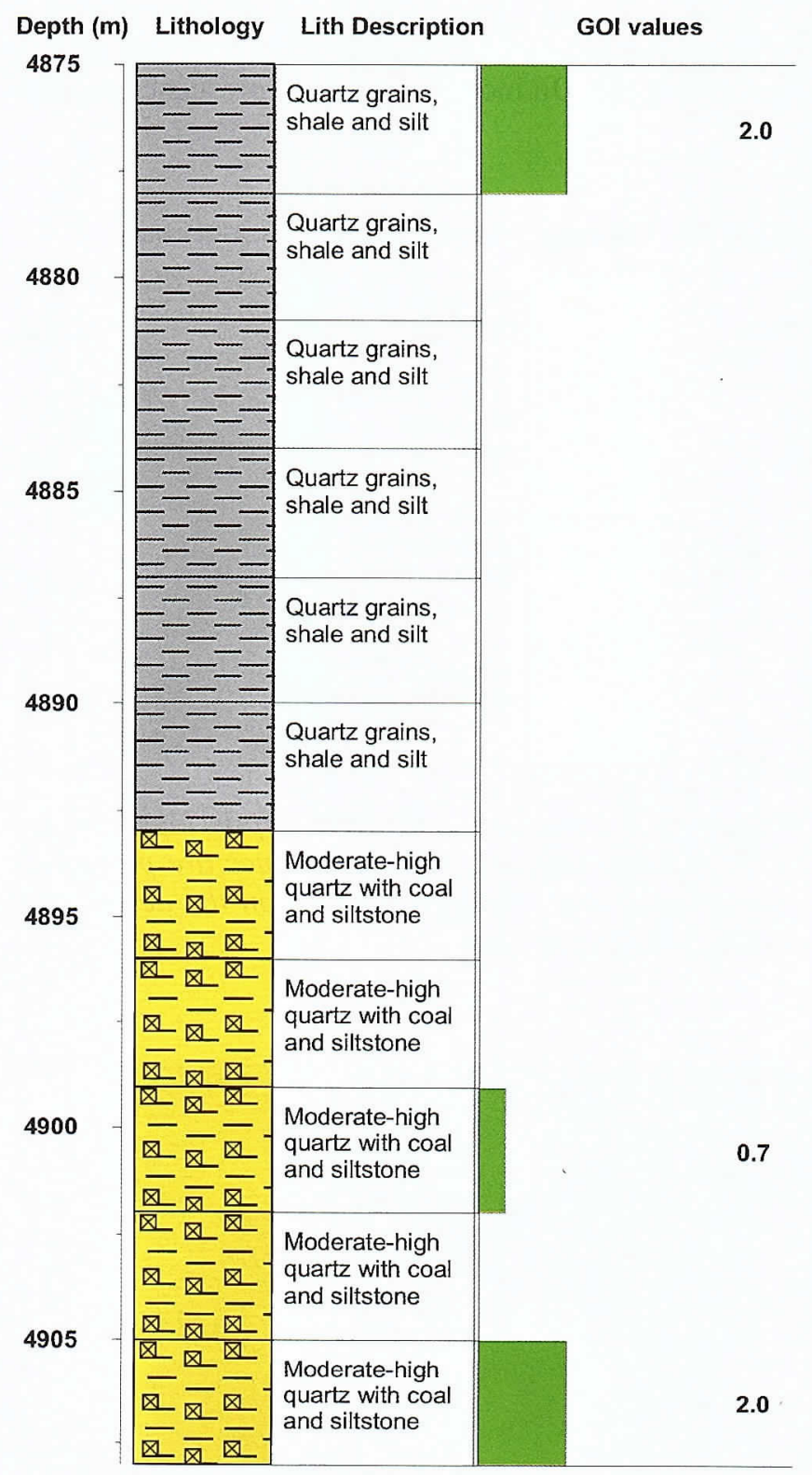

Figure 7 - Lithology and GOI logs plotted with depth for the 4875-4908 $\mathrm{m}$ interval. The GOI values are plotted as percentages and lithology is based on the description of the cuttings samples. with the samples from the oil zone. In samples from the $4875 \mathrm{~m}$ to $4908 \mathrm{~m}$ interval about $66 \%$ of oil inclusions occur in feldspar in association with altered domains in the grains and about 33\% occur in healed fractures within detrital quartz.

LOWER OIL SHOW INTERVAL SAMPLES (5367 TO $5400 \mathrm{M}$ ) GOI results for samples from this interval are 9.6 to $19 \%$ (Fig. 9). Oil inclusions in quartz and in feldspar grains in these samples are up to $15 \mu \mathrm{m}$ in diameter (Fig. 10) and many have moving vapour bubbles. Under ultraviolet illumination most inclusions exhibit near-blue fluorescence, with a lower proportion of inclusions having near-white or yellow-orange fluorescence.

Oil inclusions in the $5391 \mathrm{~m}$ and $5400 \mathrm{~m}$ samples are large and occur in high abundance in each detrital grain (Fig. 11). Oil inclusions in samples from the other depth horizons within the $5367 \mathrm{~m}$ to 5400 $\mathrm{m}$ interval, occur in high abundance but are small in size $(4 \mu \mathrm{m})$, or are isolated inclusions larger than 10 $\mu \mathrm{m}$ diameter (Fig. 10). About $55 \%$ of oil inclusions occur in feldspar in association with altered domains in the grains, $25 \%$ are located within calcite cementing porosity between quartz grains and $10 \%$ are located within monocrystalline calcite grains in the cuttings. About $10 \%$ of the oil inclusions are in healed fractures in detrital quartz. No oil inclusions were observed at the boundary between detrital quartz and overgrowths.

The GOI values for five samples from 5370 $\mathrm{m}$ to $5400 \mathrm{~m}$ are at a magnitude that is only observed in oil zone, and these samples are interpreted to have been palaeo-oil zone at the time that fluid inclusions were trapped in quartz and feldspar. These samples are in an interval with caving due to salt dissolution, and therefore the height of the palaeo-oil zone is difficult to constrain. Grains containing oil inclusions in these samples contain a high proportion of inclusions with near blue fluorescence, probably implying different attributes such as API than the inclusion oils from the other intervals. The molecular composition of the inclusion oil from the 5370-5400 $\mathrm{m}$ interval including biomarker distribution and the distribution of aromatic and low molecular weight hydrocarbons has been determined by the MCI technique (see below).

\section{MOLECULAR COMPOSITION OF INCLUSIONS}

DATA The GOI study identified two suitable samples for analysis by the MCI technique: the current oil zone (3066-3069 m) and a deeper palaeo-oil zone (5379$5382 \mathrm{~m}$ ). This paper reports the detailed hydrocarbon composition of oil trapped in the deeper sample. No data for the fluid inclusion oil from the current oil zone (3066-3069 m) are presented in this paper, because the total amounts of hydrocarbons recovered from this FI oil were too low and very close to those recovered from the system blank, raising severe doubts about the integrity of the FI oil data. Instead, we compare the MCI data with crude oil, oil show and rock extract data acquired by Petrobras on samples from the same well. 

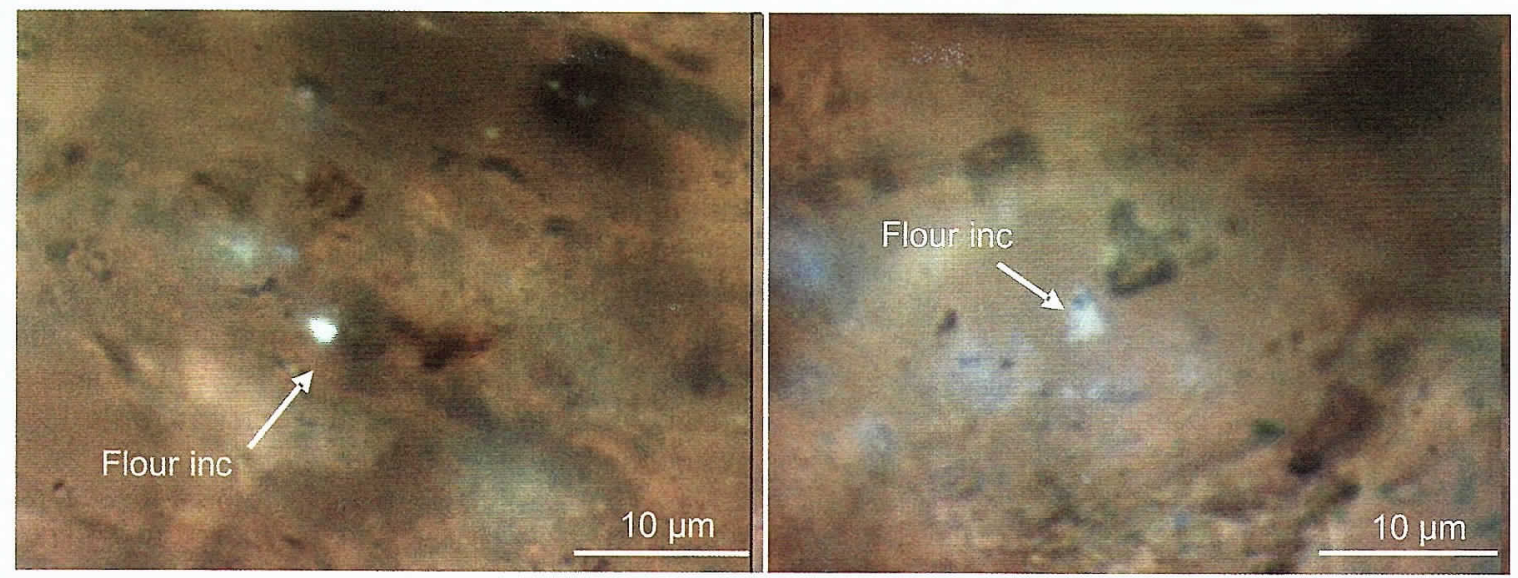

Figure 8 - Photomicrographs showing fluorescing oil inclusions from the 4875-4908 $m$ interval. Dark background ultraviolet and transmitted light, $1000 x$ magnification.

A total of $2485 \mathrm{ng}$ of $n$-alkanes in the range $n-\mathrm{C}_{12-32}$ were recovered from the 5379-5382 $\mathrm{m}$ FI oil sample. When normalized to the amount of crushed minerals this means a relative abundance of $386 \mathrm{ng}$ $n$-alkanes/g crushed rock. The corresponding system blank recovered only $9.2 \mathrm{ng} n-\mathrm{C}_{12-32}$ alkanes, i.e. 271 times less then the abundance of recovered $n-\mathrm{C}_{12-32}$ alkanes in the 5379-5382 m FI oil sample. Similarly, the final outside rinse recovered only $28.8 \mathrm{ng} n$ - $\mathrm{C}_{12}$. ${ }_{32}$ alkanes, i.e. 86 times less that the abundance of recovered $n-\mathrm{C}_{12-32}$ alkanes in the $5379-5382 \mathrm{~m}$ FI oil sample. These blanks gives very high confidence in the reported off-line data.

High quality aromatic and low molecular weight data were also acquired for the fluid inclusion oil, and support data from aliphatic hydrocarbons discussed below. However, since these data were not available for the comparison dataset of sample set from other well samples, no further discussion of these data shall be included hereafter.

N-alkanes and branched alkanes The $5379-82 \mathrm{~m}$ FI oil is characterized by a unimodal distribution of $n$-alkanes from $\mathrm{C}_{8}$ to $\mathrm{C}_{36}$, maximizing at $n$ - $\mathrm{C}_{15}$ close to that of a normal or unaltered oil on either side of the unimodal maximum (Fig. 12). No hump of unresolved complex mixture (UCM) is evident, so there is no evidence of biodegradation. Carbon preference indices over the higher molecular weight region range indicate a slight odd-over-even predominance (e.g. $\mathrm{CPI}_{22-32}=$ 1.06). This indicates only a small contribution of higher plant material to the source rock of the FI oil. The $\mathrm{Pr} /$ $n-\mathrm{C}_{17}$ and $\mathrm{Ph} / n-\mathrm{C}_{18}$ ratios (1.35 and 0.75 , respectively; Table 1) suggest that the FI oil was derived from source rocks containing type II/III kerogen and have attained a moderate maturity level. This interpretation is valid assuming that the FI oil is not biodegraded, which it does not appear to be based on any other parameter. Other isoprenoids $\left(i-\mathrm{C}_{13}\right.$ to $\left.i-\mathrm{C}_{18}\right)$ are also present in significant abundances relative to adjacent $n$-alkanes (Fig. 12). Monomethylalkanes are present in only low relative abundance. The $\mathrm{Pr} / \mathrm{Ph}$ value of 2.1 is consistent with deposition of organic matter under suboxic conditions (Didyk et al., 1978). In contrast, the $3069.5 \mathrm{~m}$ RFT crude oil is characterized by the absence of $n$-alkanes and the presence of a hump of unresolved complex mixture (UCM) in the $\mathrm{m} / \mathrm{z} 85$ mass chromatogram (Fig. 13), consistent with biodegradation. The $\mathrm{Pr} / n-\mathrm{C}_{17}$ and $\mathrm{Ph} / n-\mathrm{C}_{18}$ ratios of $>4$ (Table 1) suggest biodegradation, while the $\mathrm{Pr} / \mathrm{Ph}$ value of 1.6 suggests deposition of organic matter under suboxic conditions (Didyk et al., 1978).

Terpanes Tricyclic terpanes in both the FI oil and the RFT oil are dominated by the $\mathrm{C}_{21}, \mathrm{C}_{23}$ and $\mathrm{C}_{24}$ homologues (Table 2 and Fig. 14). In the FI oil their abundance relative to $\mathrm{C}_{30} \alpha \beta$ hopane is high, suggesting moderate to high thermal maturity, whereas in the RFT oil they have a low abundance relative to $C_{30} \alpha \beta$ hopane, suggesting low to moderate thermal maturity (Table 2). The $\mathrm{C}_{19}$ and $\mathrm{C}_{20}$ tricyclic terpanes and $\mathrm{C}_{24}$ tetracyclic terpane are in relative low abundance in both samples, consistent with a low input of terrestrial organic matter to the source rock(s). Extended tricyclic terpanes with carbon numbers $>\mathrm{C}_{28}$ are present in both samples, extending to at least $\mathrm{C}_{35}$ (Fig. 14), and the extended tricyclic terpane ratio (ETR) is moderate (Table 2), consistent with a source rich in algal and bacterial organic matter (Holba et al., 2001, 2003). The $\mathrm{C}_{26} / \mathrm{C}_{25}$ tricyclic terpane ratio of the FI oil is 0.84 (Table 2), which is evidence against a lacustrine depositional environment, whereas this ratio for the RFT oil is 1.42 , consistent with a lacustrine depositional environment (Sofer, 1993; Schiefelbein et al., 1999). The $\mathrm{C}_{23} / \mathrm{C}_{21}$ tricyclic terpane ratio of the FI oil of 1.4, similar to typical marine oils, whereas this ratio for the RFT oil is 1.26 , more similar to lacustrine oils (Sofer, 1993).

Hopanes in both the FI oil and the RFT oil are dominated by $\mathrm{C}_{30} \alpha \beta$ hopane (Fig. 15), but otherwise their distribution is significantly different. The FI oil contain high abundances of rearranged isomers including Ts, $\mathrm{C}_{29} \mathrm{Ts}$ and diahopanes (Table 2). The $\mathrm{Ts} / \mathrm{Tm}$ ratio is 


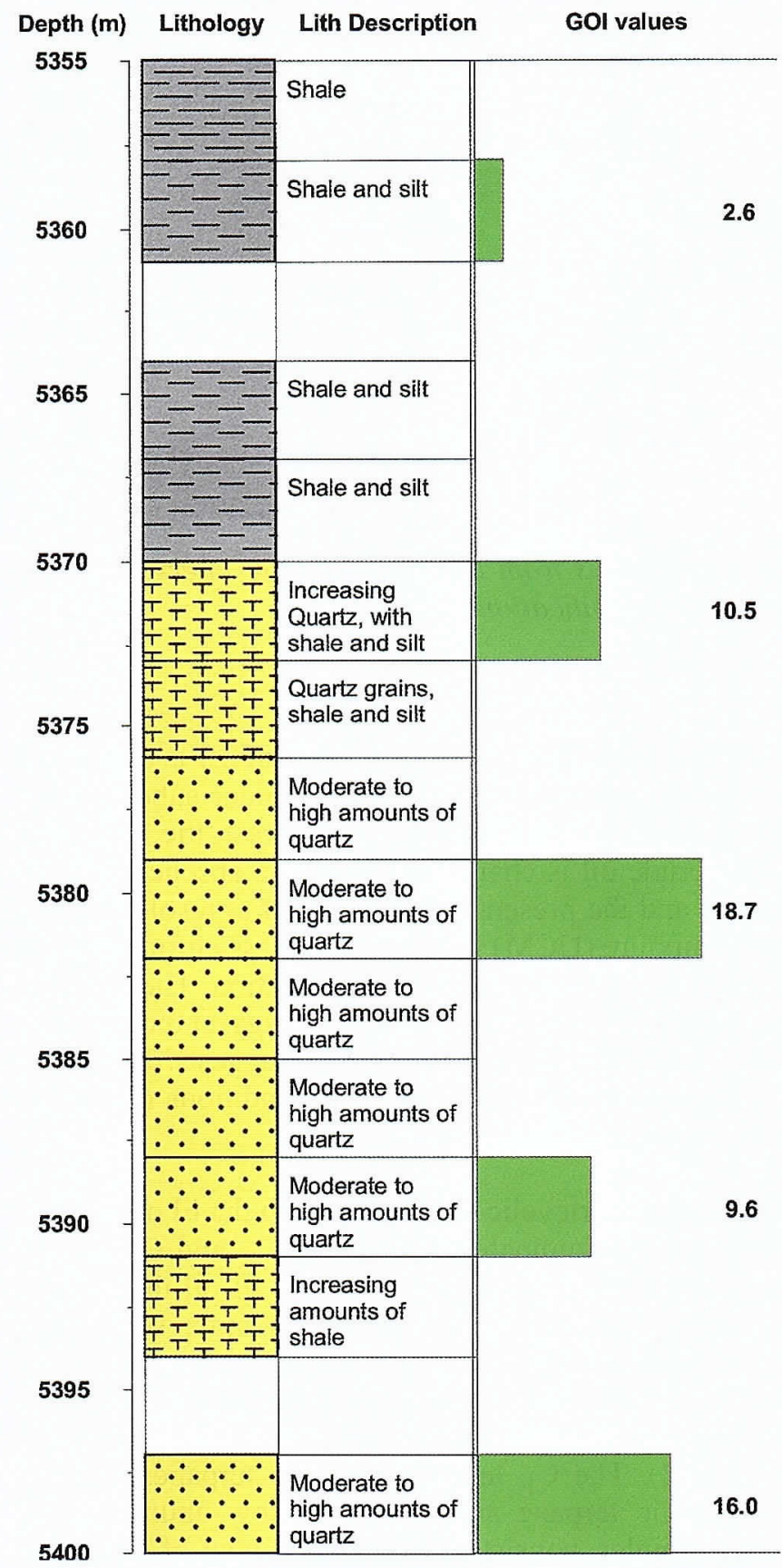

Figure 9 - Lithology and GOI logs plotted with depth for the $5355-5400 \mathrm{~m}$ interval. The GOI values are plotted as percentages and lithology is based on the description of the cuttings samples.

3.2, the $\mathrm{C}_{29} \mathrm{Ts} / \mathrm{C}_{29} \alpha \beta$ hopane ratio is 1.16 , the $\mathrm{C}_{29} \alpha \beta$ hopane $/ \mathrm{C}_{30} \alpha \beta$ hopane ratio is 0.66 and diahopanes are about $60 \%$ of the abundance of the equivalent hopane (Table 2). The FI oil also contain a series of early eluting rearranged terpanes of an undefined structure (possibly isohopanes; Nytoft, 2007) (not labelled, $\mathrm{C}_{30} \S, \mathrm{C}_{31} \S, \mathrm{C}_{32} \S$ ) which commonly co-occurs with diahopanes (Moldowan et al., 1991; Telnaes et al., 1992). The relative abundance of moretanes ( $\beta \alpha$ hopanes) is low, with $\alpha \beta /(\alpha \beta+\beta \alpha)$ hopane ratios at equilibrium values (Table 2 ). Homohopanes are of lowmoderate abundance, and the $22 S /(22 S+22 R)$ hopane ratios are also at equilibrium values. These data are consistent with sourcing of the FI oil from a mature, clay-rich source rock. The low $\mathrm{C}_{31} \alpha \beta$ hopanes $/ \mathrm{C}_{30}$ $\alpha \beta$ hopane ratio (0.79) is consistent with a lacustrine influence (Schiefelbein et al., 1999), but might also be expected in other depositional settings. In contrast, the RFT oil contains low abundances of rearranged isomers including diahopanes: the Ts/Tm ratio is 0.88 , the $\mathrm{C}_{29} \mathrm{Ts} /$ $\mathrm{C}_{29} \alpha \beta$ hopane ratio is 0.45 , the $\mathrm{C}_{29} \alpha \beta$ hopane/ $\mathrm{C}_{30} \alpha \beta$ hopane ratio is 0.56 and diahopanes are only $19 \%$ of the abundance of the equivalent hopane (Table 2).

Three bisnorhopane isomers were detected in the FI oil (25,30-BNH; 29,30-BNH; 28,30-BNH), but these are of low abundance (Table 2). The low content of 29,30-BNH is consistent with the low relative amount of $\mathrm{C}_{29} \alpha \beta$ hopane (30-norhopane) and the absence of detectable $\mathrm{C}_{30} 30$-norhopane, and provides no indication of calcareous contribution to the source rock. The relative abundance of $2 \alpha$-methylhopanes is low, and therefore does not indicate a significant input of prokaryotic organic matter in a calcareous depositional environment (Summons and Jahnke, 1990). The gammacerane $/ \mathrm{C}_{30} \alpha \beta$ hopane ratio is higher in the RFT oil than in the FI oil (Table 2), certainly indicating a lacustrine source for the RFT oil (Fig. 15). Oleanane and bicadinanes are absent in both oils. The low content of $25,30-\mathrm{BNH}$ is consistent with the detection of only very low amounts of $\mathrm{C}_{27} 22,28,30$-trisnorhopane (TNH) and $\mathrm{C}_{29}$ 25-norhopane in the FI oil (Table 2). In contrast, the presence of abundant demethylated hopanes in the RFT oil $\left(\mathrm{C}_{29} 25\right.$-norhopane $/ \mathrm{C}_{29} \alpha \beta$ hopane $\left.=0.49\right)$ is clear evidence of biodegradation (Volkman et al., 1983).

STERANES AND DIASTERANES Sterane and diasterane ratios for the FI and RFT oils are reported in table 3. The $\mathrm{C}_{21}$ and $\mathrm{C}_{22}$ steranes pregnane and homopregnane are present in moderate to high amounts in the FI oil (Table 3), consistent with the thermal maturity corresponding to the oil window, whereas these are of lower abundance in the RFT oil. In the FI oil, diasteranes are more abundant than regular steranes at all carbon numbers (Fig. 16), so diasterane/sterane ratios vary from 3-4 (Table 3). This is consistent with the high amounts of rearranged hopanes in this sample, and is also consistent with sourcing of the FI oil from a mature, clay-rich source rock. In contrast, diasteranes are less abundant than steranes in the RFT oil (Table 3 ). The sterane and diasterane distributions for the FI oil are all dominated by the $\mathrm{C}_{27}$ homologues, with similar and low amounts of $\mathrm{C}_{28}$ and $\mathrm{C}_{29}$ steranes (Table 3), whereas the RFT oil contains similar amounts of $\mathrm{C}_{27}$ and $\mathrm{C}_{29}$ homologues. The distribution of $\alpha \beta \beta$ steranes from the $\mathrm{m} / \mathrm{z} 218$ mass chromatogram of the FI oil is 50:20:30, whereas the RFT oil has a distribution of $42: 17: 42$. Small amounts of $n$-propylcholestanes are present in the FI oil, with a $\mathrm{C}_{30} \alpha \alpha \alpha 20 R /\left(\mathrm{C}_{27}+\mathrm{C}_{28}+\mathrm{C}_{29}\right)$ a $\alpha \alpha 20 R$ sterane ratio of 1.7, indicating a marine depositional environment for the source rock of the FI oil (Moldowan et al., 1990). These carbon number distributions are consistent with a dominantly marine algal contribu- 

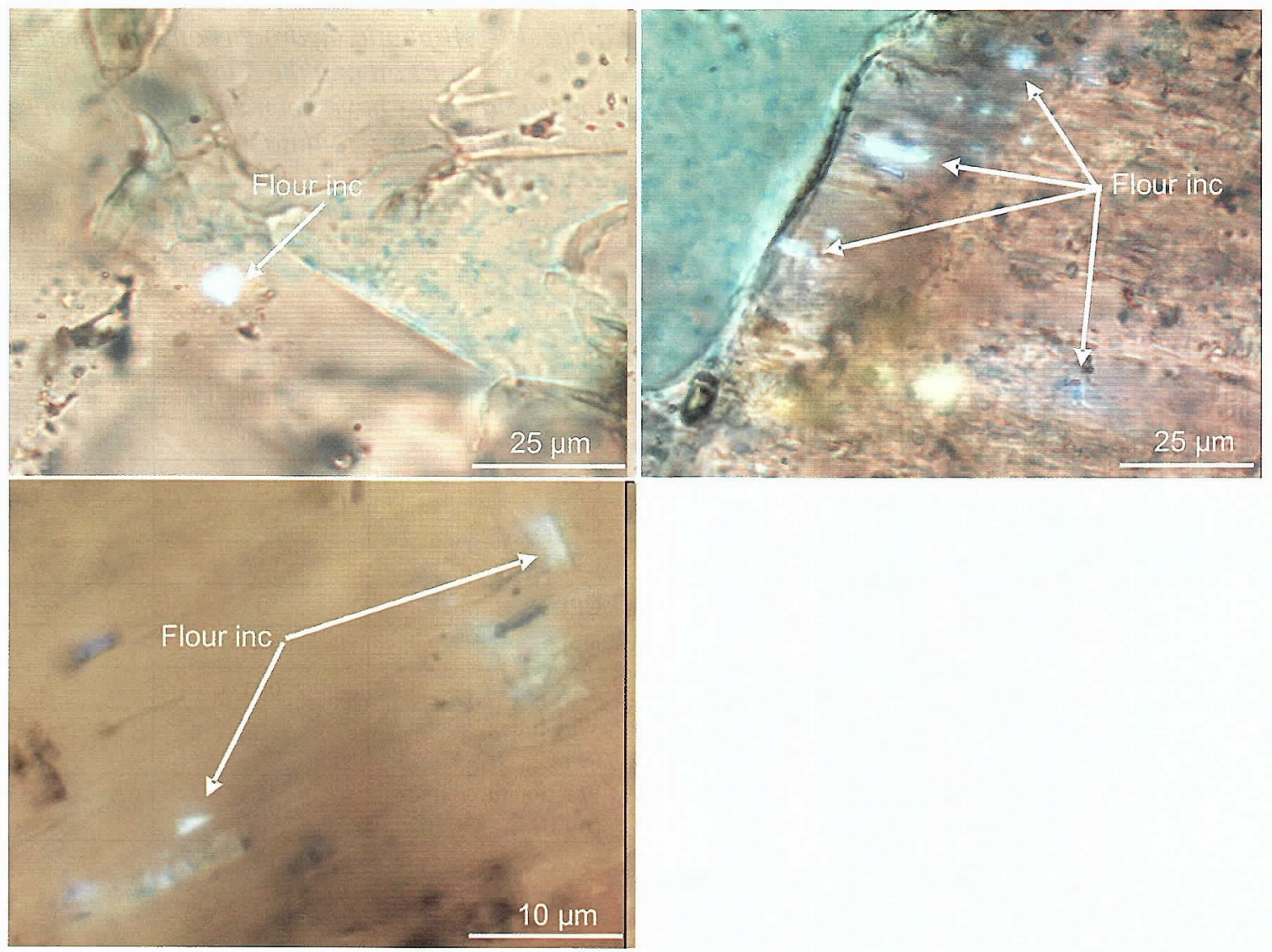

Figure 10 - Photomicrographs showing hydrocarbon petrographic features from the 5367-5391 m interval. Inset $G, H$ and I show oil inclusions from a deep oil show samples ( $G$ and $H=5370 \mathrm{~m}$, 600x mag, $I=5382 \mathrm{~m} 1800 \times \mathrm{mag}$ ) with $U / V$ and transmitted light.
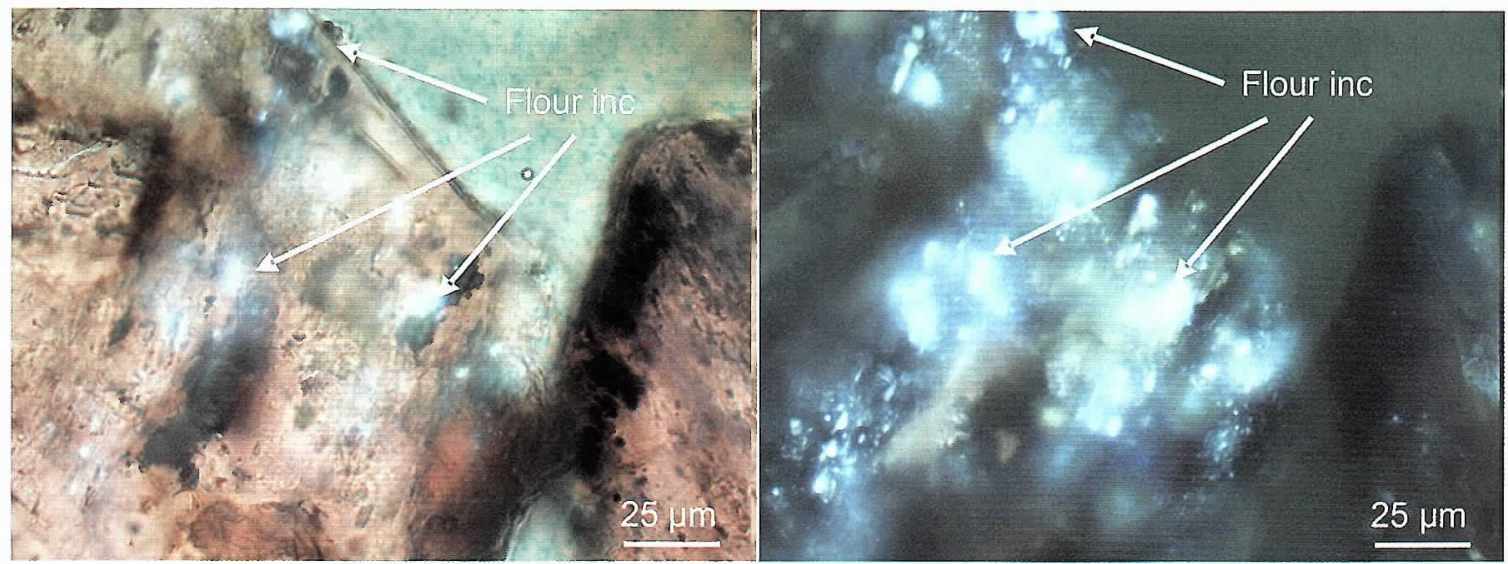

Figure 11 - Photomicrographs showing fuorescing oil inclusions in feldspar in samples from the 5367-5391 m interval; $J$.- ultraviolet illumination and transmitted light, $K$ - ultraviolet illumination, $500 \times$ magnification.

tion to the source rock, with limited terrestrial organic matter. In contrast, no $n$-propylcholestanes could be detected in the RFT oil, suggesting a lacustrine depositional environment for its source rock (Moldowan et al., 1990). The abundance of $2 \alpha$-methylsteranes and $3 \beta-$ methylsteranes is low in the FI oil, and no dinosteranes could be positively identified. The FI oil contains $\mathrm{C}_{26}$ diasteranes (nordiacholestanes) and steranes (norcholestanes) (Fig. 16). Apart from the 21-norcholestane isomer, which may increase in relative abundance with maturity, there are two main series of norcholestanes and nordiacholestanes. The 27-nor series is abundant in older rocks, whereas in Cretaceous and Tertiary rocks the 24-nor series becomes more abundant (Holba et al., 


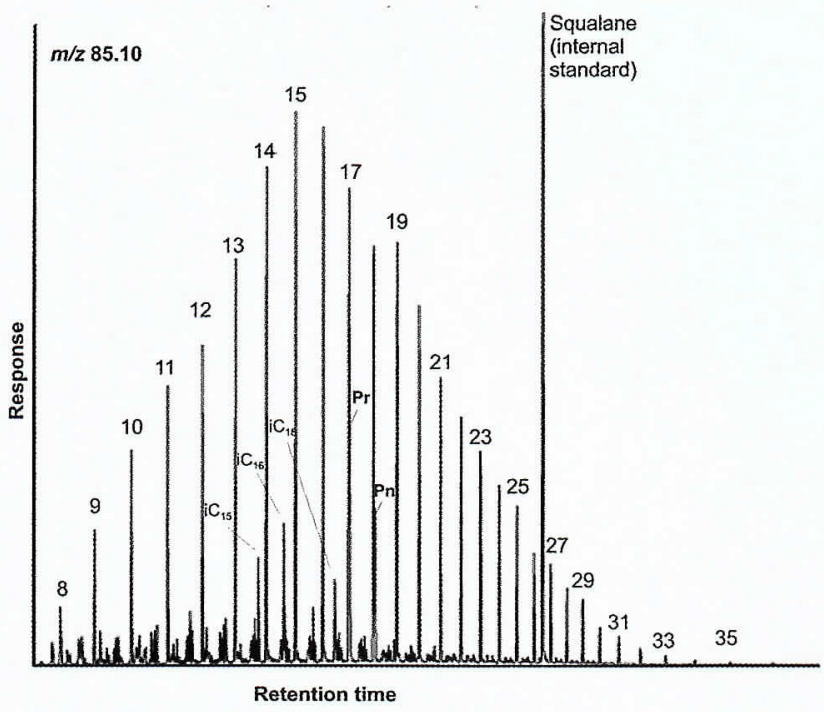

Figure 12 - Partial m/z 85.10 mass chromatogram of fluid inclusion oil from 5379-82 $\mathrm{m}$. Numbers refer to n-alkane chain length, $\mathrm{Pr}=$ pristane, $\mathrm{Ph}=$ phytane, $i C 15=C 15$ isoprenoid, etc

1998a, 1998b). Two ratios, the NDR (nordiacholestanes ratio) and the NCR (norcholestanes ratio), quantify this (Table 3). NDR values above a threshold of 0.25 and NCR values above a threshold of 0.35 are consistent with Cretaceous or younger rocks. NDR values above a threshold of 0.5 and NCR values above a threshold of 0.6 are consistent with Tertiary rocks (Holba et al., $1998 \mathrm{a}, 1998 \mathrm{~b})$. The NDR (0.28) and NCR (0.50) values for the FI oil therefore suggest that it was derived from a Cretaceous source rock.

The relative abundance of the tetracyclic
Table 1 - Aliphatic hydrocarbon parameters of the 5379-5382 m FI oil and the 3069.5m RFT oil. Note that isoprenoid ratios have been calculated from responsefactor modified $\mathrm{m} / \mathrm{z} 85$ data.

\begin{tabular}{l|c|c}
\hline Parameter & 5379-82 m FI oil & $\begin{array}{c}\text { RFT 3069.5m RFT } \\
\text { oil }\end{array}$ \\
\hline $\mathrm{Pr} / \mathrm{Ph}$ & 2.1 & 1.60 \\
\hline $\mathrm{Pr} / n-\mathrm{C}_{17}$ & 1.35 & 4.60 \\
\hline $\mathrm{Ph} / n-\mathrm{C}_{18}$ & 0.75 & 4.70 \\
\hline $\mathrm{CPI}_{22-32}$ & 1.06 & - \\
\hline $\mathrm{CPI}_{24-32}$ & 1.09 & - \\
\hline $\mathrm{CPI}_{26-32}$ & 1.11 & - \\
\hline $\mathrm{CPI}_{26-30}$ & 1.09 & - \\
\hline $\mathrm{CPI} 2_{26-28}$ & 1.06 & - \\
\hline $\mathrm{CPI} 2_{28-30}$ & 1.13 & - \\
\hline $\mathrm{CPI} 2$ & - \\
\hline$n-\mathrm{C}_{31} / n-\mathrm{C}_{19}$ & 0.97 & - \\
\hline $\begin{array}{l}\text { Wax Index } \\
\left(n-\mathrm{C}_{21-22} / n-\mathrm{C}_{28-29}\right)\end{array}$ & 0.11 & - \\
\hline $\begin{array}{l}\text { Fractionation index } \\
\left(\mathrm{n}-\mathrm{C}_{10} / \mathrm{n}-\mathrm{C}_{16-25}\right)\end{array}$ & 3.40 & - \\
\hline
\end{tabular}

polyprenoids $\mathrm{Ta}$ and $\mathrm{Tb}$ is low in the FI oil (Fig. 17 and Table 3), more similar to that of marine oils than lacustrine oils (cf. Schiefelbein et al., 1999). In contrast, the relative abundance of $\mathrm{Ta}$ and $\mathrm{Tb}$ in the RFT oil is relatively high $(0.72$; Table 3$)$, with greater abundance relative to the steranes, and thus is more similar to that of lacustrine oils (cf. Schiefelbein et al., 1999).

Thermal maturity parameters determined from

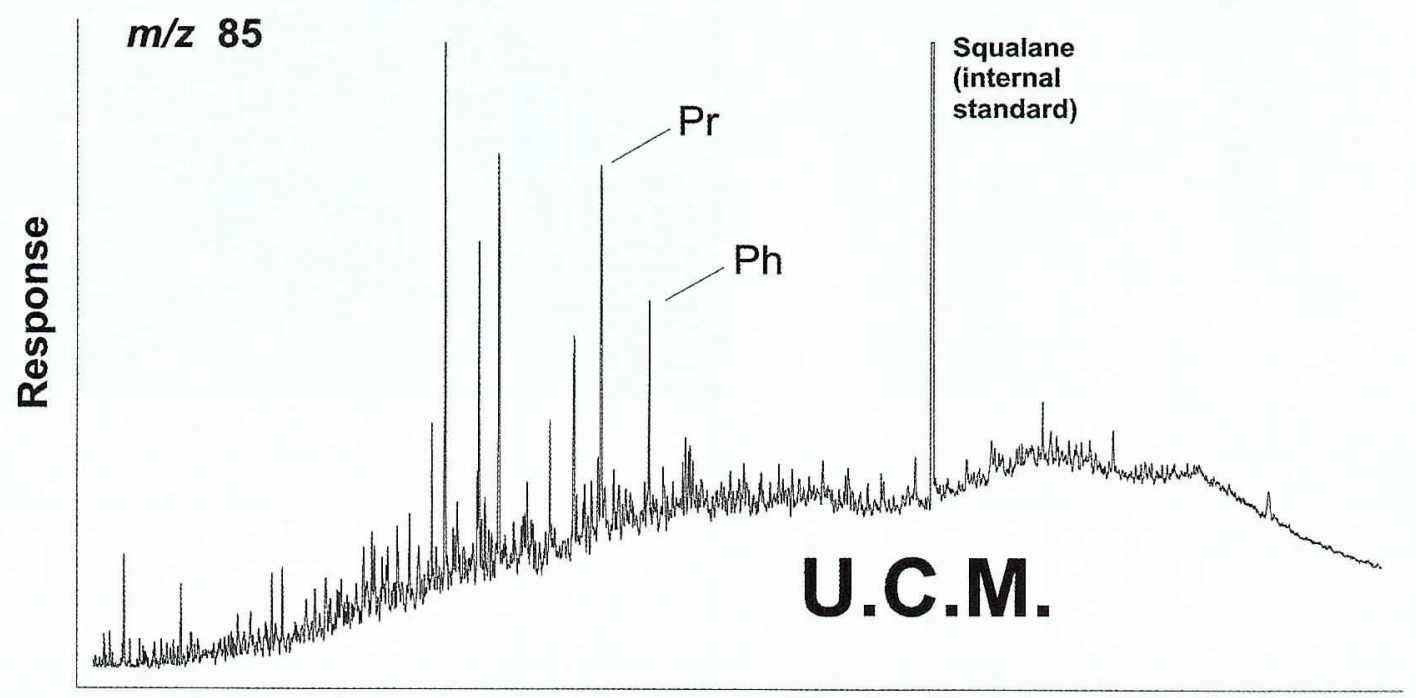

Retention time

Figure 13 - Partial m/z 85.10 mass chromatogram of the RFT oil from $3069.5 \mathrm{~m}$. Labels as in figure 12. 
Table 2 - Terpane parameters of the 5379-5382 m FI oil and the 3069.5m RFT oil.

\begin{tabular}{|c|c|c|c|}
\hline Parameter & FI oil & RFT oil & Transition \\
\hline $\mathrm{Ts} / \mathrm{Tm}$ & 3.2 & 0.88 & M \\
\hline $\mathrm{Ts} /(\mathrm{Ts}+\mathrm{Tm})$ & 0.76 & 0.47 & M \\
\hline $\mathrm{Tm} / \mathrm{C}_{27} \beta$ & 12.6 & nd & $\mathrm{M}$ \\
\hline $\mathrm{C}_{29} \mathrm{Ts}_{\mathrm{s}} \mathrm{C}_{29} \alpha \beta$ hopane & 1.16 & 0.45 & M \\
\hline $\mathrm{C}_{29} \mathrm{Ts} /\left(\mathrm{C}_{29} \mathrm{Ts}+\mathrm{C}_{29} \alpha \beta\right.$ hopane $)$ & 0.54 & 0.31 & M \\
\hline $\mathrm{C}_{30} * / \mathrm{C}_{29} \mathrm{Ts}$ & 1.04 & 1.02 & S191 \\
\hline $\mathrm{C}_{29} * / \mathrm{C}_{29} \alpha \beta$ hopane & 0.64 & nd & M \\
\hline $\mathrm{C}_{30} * / \mathrm{C}_{30} \alpha \beta$ hopane & 0.60 & 0.19 & M \\
\hline $\mathrm{C}_{30} \S / \mathrm{C}_{30} \alpha \beta$ hopane & 0.19 & nd & M \\
\hline $\mathrm{C}_{29}$ 25-norhopane $/ \mathrm{C}_{29} \alpha \beta$ hopane & 0.04 & 0.49 & M \\
\hline$C_{29} \alpha \beta /(\alpha \beta+\beta \alpha)$ hopanes & 0.92 & 0.90 & M \\
\hline$C_{30} \alpha \beta /(\alpha \beta+\beta \alpha)$ hopanes & 0.95 & 0.88 & $\mathrm{M}$ \\
\hline $\mathrm{C}_{31} \alpha \beta 22 S /(22 S+22 R)$ hopanes & 0.60 & 0.70 & M \\
\hline $\mathrm{C}_{32} \alpha \beta 22 S /(22 S+22 R)$ hopanes & 0.60 & 0.57 & M \\
\hline $\mathrm{C}_{33} \alpha \beta 22 S /(22 S+22 R)$ hopanes & 0.59 & 0.61 & M \\
\hline$\% \mathrm{C}_{31}$ of total $\alpha \beta$ homohopanes & 35.5 & 35.6 & S191 \\
\hline$\% \mathrm{C}_{32}$ of total $\alpha \beta$ homohopanes & 24.9 & 18.8 & S191 \\
\hline$\% \mathrm{C}_{33}$ of total $\alpha \beta$ homohopanes & 16.6 & 13.9 & S191 \\
\hline$\% \mathrm{C}_{34}$ of total $\alpha \beta$ homohopanes & 12.9 & 19.0 & S191 \\
\hline$\% \mathrm{C}_{35}$ of total $\alpha \beta$ homohopanes & 10.0 & 12.6 & S191 \\
\hline $\mathrm{C}_{35} /\left(\mathrm{C}_{35}+\mathrm{C}_{34}\right)$ homohopanes & 0.44 & 0.40 & S191 \\
\hline Homohopanes $/ \mathrm{C}_{30} \alpha \beta$ hopane & 2.20 & 0.44 & S191 \\
\hline Gammacerane $/ C_{30} \alpha \beta$ hopane & 0.17 & 0.31 & M \\
\hline $\mathrm{Ts} / \mathrm{C}_{30} \alpha \beta$ hopane & 0.76 & 0.21 & S191 \\
\hline $28,30-\mathrm{BNH} / \mathrm{C}_{30} \alpha \beta$ hopane & 0.06 & nd & M \\
\hline 28,30-BNH/Ts & 0.06 & nd & $\mathrm{M}$ \\
\hline $\mathrm{C}_{29} \alpha \beta$ hopane $/ \mathrm{C}_{30} \alpha \beta$ hopane & 0.66 & 0.56 & S191 \\
\hline$C_{31} \alpha \beta$ hopanes/ $C_{30} \alpha \beta$ hopane & 0.79 & 0.98 & S191 \\
\hline $\mathrm{C}_{26} / \mathrm{C}_{25}$ tricyclic terpanes & 0.84 & 1.42 & S191 \\
\hline $\mathrm{C}_{23}$ tricyclic terpane $/ \mathrm{C}_{30} \alpha \beta$ hopane & 1.24 & 0.98 & S191 \\
\hline $\mathrm{C}_{24}$ tetracyclic terpane/ $\mathrm{C}_{30} \alpha \beta$ hopane & 0.22 & 0.10 & S191 \\
\hline $\mathrm{C}_{23} / \mathrm{C}_{21}$ tricyclic terpanes & 1.40 & 1.26 & S191 \\
\hline $\mathrm{C}_{23-26} / \mathrm{C}_{19-21}$ tricyclic terpanes & 1.80 & 2.02 & S191 \\
\hline $\mathrm{C}_{24}$ tetracyclic/ $\mathrm{C}_{26}$ tricyclic terpanes & 0.37 & 0.14 & S191 \\
\hline $\mathrm{C}_{24}$ tetracyclic/ $\mathrm{C}_{23}$ tricyclic terpanes & 0.18 & 0.10 & S191 \\
\hline$\left(\mathrm{C}_{19}+\mathrm{C}_{20}\right) / \mathrm{C}_{23}$ tricyclic terpanes & 0.76 & 0.38 & S191 \\
\hline $\begin{array}{l}\mathrm{C}_{24} \text { tetracyclic } /\left(\mathrm{C}_{24} \text { tetracyclic }+\mathrm{C}_{23} \text { tricyclic }\right. \\
\text { terpane })\end{array}$ & 0.15 & 0.09 & S191 \\
\hline $\mathrm{C} 19 /(\mathrm{C} 19+\mathrm{C} 23$ tricyclic terpanes $)$ & 0.28 & 0.07 & S191 \\
\hline $\mathrm{C}_{29}$ tricyclic terpanes / $\mathrm{C}_{30} \alpha \beta$ hopane & 0.71 & 0.69 & S191 \\
\hline $\begin{array}{l}\text { ETR (Extended Tricyclic ratio) }(28 / 3+29 / 3) / \\
\text { Ts }\end{array}$ & 1.8 & 0.86 & S191 \\
\hline $\mathrm{C}_{29}$ steranes $/ \mathrm{C}_{29} \alpha \beta$ hopanes & 1.03 & 0.54 & $\mathrm{~S} 191+217$ \\
\hline
\end{tabular}

Transition: ratios were calculated from MRM data (M) or SIM data (S, showing ion used). 


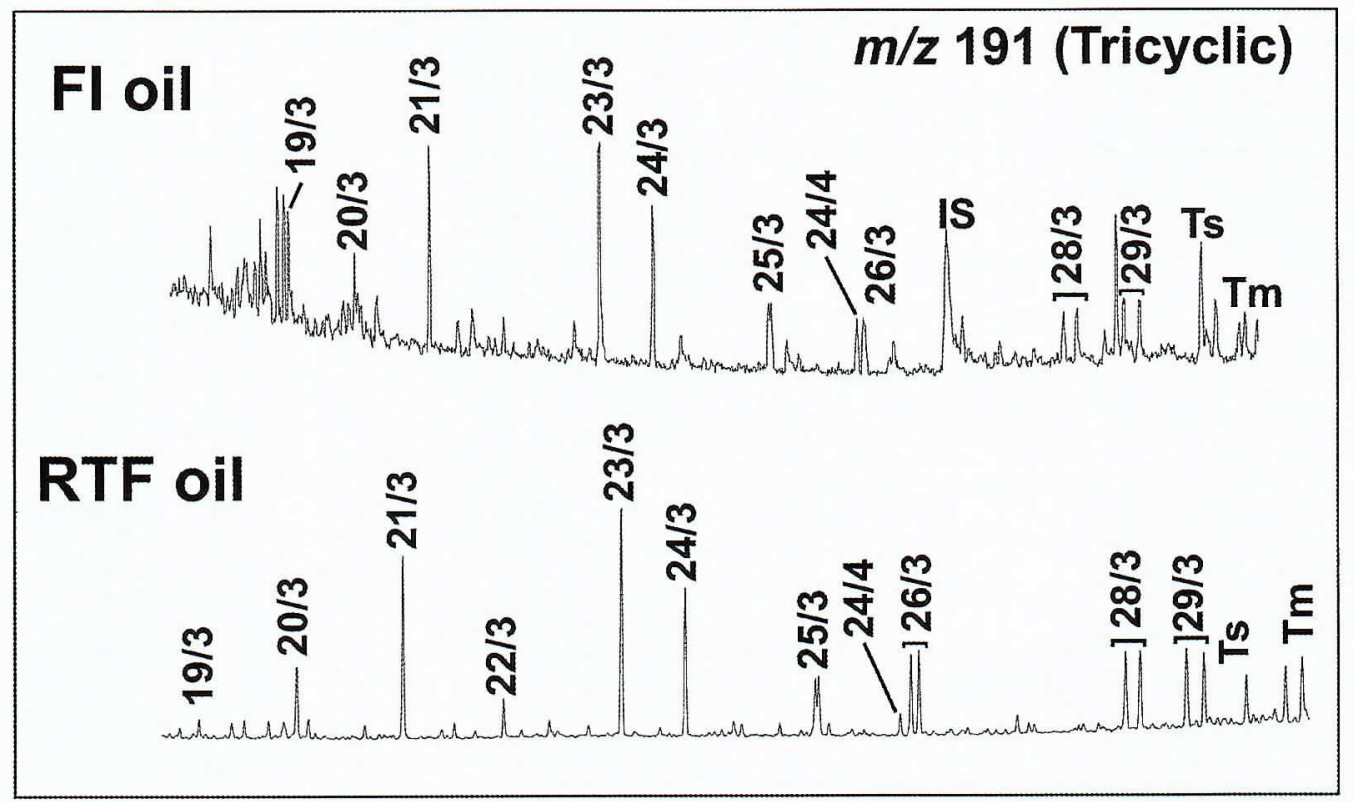

Figure 14 - Partial m/z 191.18 mass chromatograms for the 5379-5382 m FI oil and the $3069.5 \mathrm{~m}$ RFT oil, showing the distribution tricyclic and tetracyclic terpanes. 19/3 refers to C19 tricyclic terpane, 24/4 refers to C24 tetracyclic terpane, and so on.

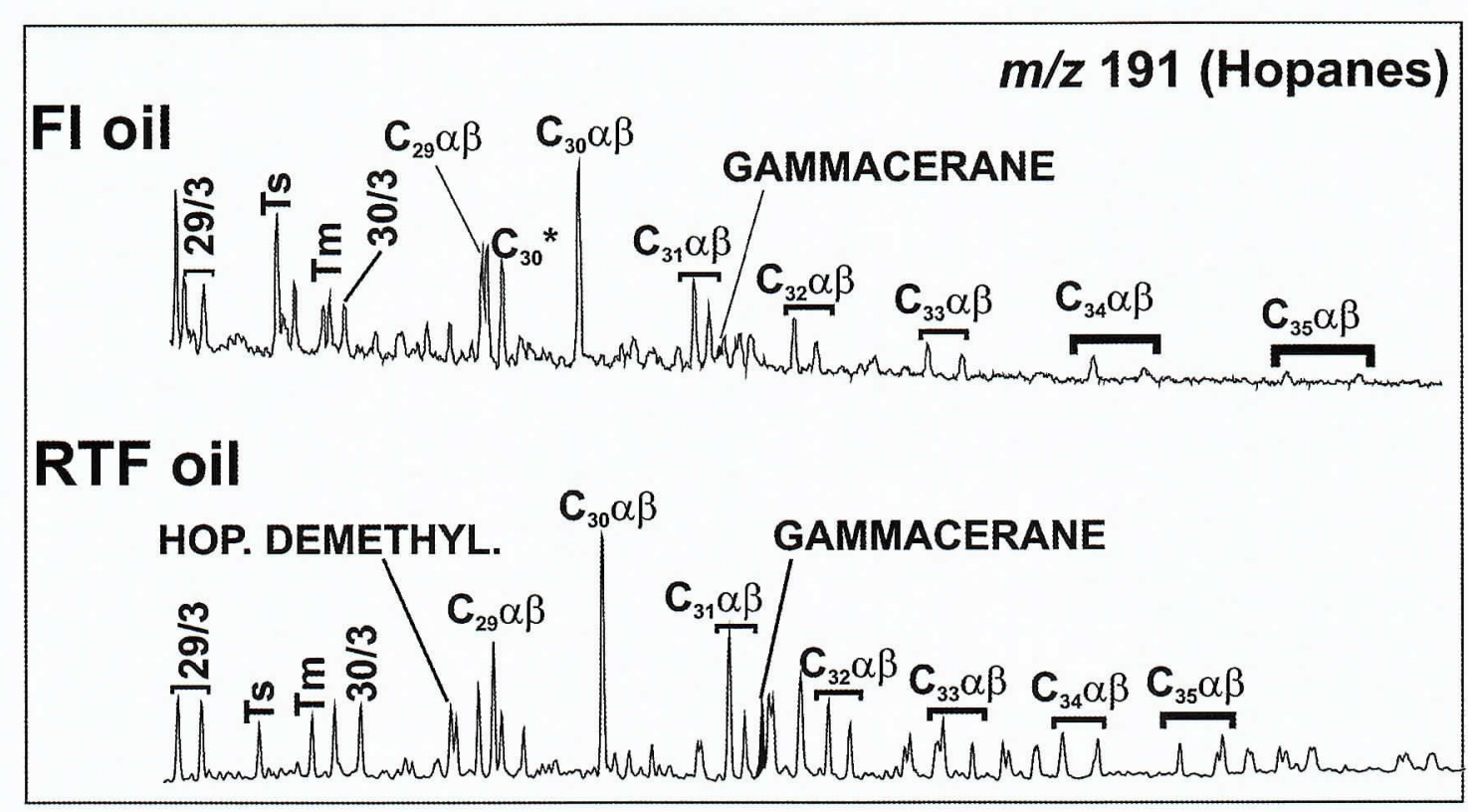

Fig. 15 - Partial m/z 191.18 mass chromatograms for the $5379-5382 \mathrm{~m}$ FI oil and the $3069.5 \mathrm{~m}$ RFT oil, showing the distribution of hopanes.

the steranes and diasteranes support a thermal maturity in the peak oil window for the FI oil and the RFT oil (Table 3). The $\beta \alpha$ diasterane $20 S /(20 S+20 R)$ ratios are close to or above their expected thermal endpoints of about 0.6 , which are reached at the onset of oil generation (Mackenzie et al., 1980). The $\mathrm{C}_{29}$ and $\mathrm{C}_{28}$ sterane $\alpha \alpha \alpha 20 S /(20 S+20 R)$ ratios are 0.50 and 0.54 , and thus also close to the empirical end values, which according to Mackenzie (1984) is reached at about 0.8\% vitrinite reflectance. When applying a correlation of $\mathrm{C}_{29}$ sterane $\alpha \alpha \alpha 20 S / 20 R$ with vitrinite reflectance (Sofer et al., 1993), the vitrinite reflectance equivalent (VRE) value is 0.86 (Table 3 ). This is supported by the values of $C_{29} \alpha \beta \beta /(\alpha \beta \beta+\alpha \alpha \alpha)$ steranes, which are around 0.6 and thus haven't reached the theoretical endpoint of 0.7 in the peak oil window (Seifert and Moldowan, 1986). INTERPRETATION In this section data from the 5379-5382 m FI oil sample are interpreted with respect to its secondary alteration (biodegradation, water washing or evaporative fractionation), source quality 
Table 3 - Sterane and diasterane parameters 5379-5382 m FI oil and the 3069.5m RFT oil.

\begin{tabular}{|c|c|c|c|}
\hline Parameter & $\begin{array}{l}5379-82 \mathrm{~m} \text { FI } \\
\text { oil }\end{array}$ & $\begin{array}{l}3069.5 \mathrm{~m} \mathrm{RFT} \\
\text { oil }\end{array}$ & Transition \\
\hline $\mathrm{C}_{21}$ sterane $/ \mathrm{C}_{29} \alpha \alpha \alpha 20 \mathrm{R}$ sterane & 3.60 & 0.54 & S217 \\
\hline $\mathrm{C}_{22}$ sterane/ $\mathrm{C}_{29} \alpha . \alpha \alpha 20 \mathrm{R}$ sterane & 0.97 & 0.22 & S217 \\
\hline NDR (24-nor/(24-nor+27-nor) nordiacholestanes & 0.28 & n.d. & M \\
\hline NCR (24-nor/(24-nor+27-nor) norcholestanes & 0.50 & n.d. & M \\
\hline $\mathrm{C}_{26}$ steranes: 21-nor/(21-nor+ $\alpha \alpha \alpha$ 20R 24-nor) & 0.45 & n.d. & M \\
\hline $\mathrm{C}_{26}$ steranes: 21-nor/(21-nor+ $\alpha \alpha \alpha$ 20R 27-nor) & 0.39 & n.d. & M \\
\hline $\mathrm{C}_{27} \alpha \alpha \alpha 20 \mathrm{R}$ (\% of total $\mathrm{C}_{27}$ to $\mathrm{C}_{29} \alpha \alpha \alpha 20 \mathrm{R}$ steranes) & 59.20 & 46.50 & S217 \\
\hline $\mathrm{C}_{28} \alpha \alpha \alpha 20 \mathrm{R}$ (\% of total $\mathrm{C}_{27}$ to $\mathrm{C}_{29} \alpha \alpha \alpha$ 20R steranes) & 18.10 & 14.80 & S217 \\
\hline $\mathrm{C}_{29} \alpha \alpha \alpha 20 \mathrm{R}$ (\% of total $\mathrm{C}_{27}$ to $\mathrm{C}_{29} \alpha \alpha \alpha 20 \mathrm{R}$ steranes) & 22.70 & 38.70 & S217 \\
\hline $\mathrm{C}_{29} \alpha \alpha \alpha 20 \mathrm{R} / \mathrm{C}_{27} \alpha \alpha \alpha 20 \mathrm{R}$ steranes & 0.38 & 0.83 & S217 \\
\hline $\mathrm{C}_{28} \alpha \alpha \alpha 20 \mathrm{R} / \mathrm{C}_{29} \alpha \alpha \alpha 20 \mathrm{R}$ steranes & 0.80 & 0.38 & S217 \\
\hline $\mathrm{C}_{30} /\left(\mathrm{C}_{27}+\mathrm{C}_{28}+\mathrm{C}_{29}\right) \alpha \alpha \alpha 20 \mathrm{R}$ steranes (\%) & 1.70 & 0 & M \\
\hline $\begin{array}{l}\mathrm{C}_{27} \alpha \beta \beta \text { steranes } 20 \mathrm{~S}+\mathrm{R}\left(\% \text { of total } \mathrm{C}_{27} \text { to } \mathrm{C}_{29} \alpha \beta \beta 20 \mathrm{R}\right. \\
\text { steranes }\end{array}$ & 50.40 & 40.00 & S218 \\
\hline $\begin{array}{l}\mathrm{C}_{28} \alpha \beta \beta \text { steranes } 20 \mathrm{~S}+\mathrm{R}\left(\% \text { of total } \mathrm{C}_{27} \text { to } \mathrm{C}_{29} \alpha \beta \beta 20 \mathrm{R}\right. \\
\text { steranes }\end{array}$ & 20.10 & 21.00 & S218 \\
\hline $\begin{array}{l}\mathrm{C}_{29} \alpha \beta \beta \text { steranes } 20 \mathrm{~S}+\mathrm{R}\left(\% \text { of total } \mathrm{C}_{27} \text { to } \mathrm{C}_{29} \alpha \beta \beta 20 \mathrm{R}\right. \\
\text { steranes }\end{array}$ & 29.50 & 38.00 & S218 \\
\hline$C_{29} \alpha \beta \beta$ steranes $20 \mathrm{~S}+\mathrm{R} / \mathrm{C}_{27} \alpha \beta \beta$ steranes $20 \mathrm{~S}+\mathrm{R}$ & 0.83 & 0.96 & M \\
\hline$C_{27} \alpha \beta \beta$ steranes $20 S+R / C_{29} \alpha \beta \beta$ steranes $20 S+R$ & 1.20 & 1.03 & M \\
\hline$\left(\mathrm{C}_{27}\right.$ steranes + diasteranes $) /\left(\mathrm{C}_{29}\right.$ steranes + diasteranes $)$ & 2.00 & & M \\
\hline $\mathrm{C}_{27}$ steranes ( $\%$ of total $\mathrm{C}_{27}$ to $\mathrm{C}_{29}$ regular steranes) & 48.90 & 41.60 & M \\
\hline $\mathrm{C}_{28}$ steranes ( $\%$ of total $\mathrm{C}_{27}$ to $\mathrm{C}_{29}$ regular steranes) & 20.60 & 17.30 & M \\
\hline $\mathrm{C}_{29}$ steranes (\% of total $\mathrm{C}_{27}$ to $\mathrm{C}_{29}$ regular steranes) & 30.50 & 41.10 & M \\
\hline $\mathrm{C}_{29} / \mathrm{C}_{27} \beta \alpha$ diasteranes & 0.44 & - & M \\
\hline $\mathrm{C}_{30} /\left(\mathrm{C}_{27}-\mathrm{C}_{30}\right) \beta \alpha$ diasteranes $(\%)$ & 1.40 & - & $\mathrm{M}$ \\
\hline $\begin{array}{l}\mathrm{C}_{27} \beta \alpha \text { diasterane } 20 \mathrm{~S}+\mathrm{R}\left(\% \text { of total } \mathrm{C}_{27} \text { to } \mathrm{C}_{29} \beta \alpha 20 \mathrm{~S}+\mathrm{R}\right. \\
\text { diasteranes }\end{array}$ & 42.40 & - & S259 \\
\hline $\begin{array}{l}\mathrm{C}_{28} \beta \alpha \text { diasterane } 20 \mathrm{~S}+\mathrm{R}\left(\% \text { of total } \mathrm{C}_{27} \text { to } \mathrm{C}_{29} \beta \alpha 20 \mathrm{~S}+\mathrm{R}\right. \\
\text { diasteranes }\end{array}$ & 31.20 & - & S259 \\
\hline $\begin{array}{l}\mathrm{C}_{29} \beta \alpha \text { diasterane } 20 \mathrm{~S}+\mathrm{R}\left(\% \text { of total } \mathrm{C}_{27} \text { to } \mathrm{C}_{29} \beta \alpha 20 \mathrm{~S}+\mathrm{R}\right. \\
\text { diasteranes }\end{array}$ & 26.40 & - & S259 \\
\hline $\mathrm{C}_{27} \beta \alpha$ diasteranes $/(\alpha \alpha \alpha+\alpha \beta \beta$ steranes $)$ & 4.10 & 0.52 & M \\
\hline $\mathrm{C}_{29} \alpha \alpha \alpha 20 \mathrm{~S} /(20 \mathrm{~S}+20 \mathrm{R})$ & 0.50 & 0.53 & M \\
\hline $\mathrm{C}_{29} \alpha \alpha \alpha 20 \mathrm{~S} / 20 \mathrm{R}$ & 1.01 & 1.12 & M \\
\hline Vitrinite reflectance equivalent from $\mathrm{C}_{29} \alpha \alpha \alpha 20 \mathrm{~S} / 20 \mathrm{R}$ & 0.86 & & M \\
\hline $\mathrm{C}_{27} \alpha \beta \beta /(\alpha \beta \beta+\alpha \alpha \alpha)$ & n.d. & 0.66 & \\
\hline $\mathrm{C}_{28} \alpha \beta \beta /(\alpha \beta \beta+\alpha \alpha \alpha)$ & 0.63 & 0.78 & M \\
\hline $\mathrm{C}_{29} \alpha \beta \beta /(\alpha \beta \beta+\alpha \alpha \alpha)$ & 0.61 & 0.64 & M \\
\hline $\mathrm{C}_{27} \beta \alpha$ diasterane 20S $/(20 \mathrm{~S}+20 \mathrm{R})$ & 0.62 & 0.57 & M \\
\hline $\begin{array}{l}\mathrm{TPP}(\text { Tetracyclic polyprenoids ratio })=(\mathrm{Ta}+\mathrm{Tb}) / \mathrm{C}_{27} \beta \alpha \\
\text { diasteranes }\end{array}$ & 0.16 & 0.72 & S259 \\
\hline
\end{tabular}

Transition: ratios were calculated from MRM data (M) or SIM data (S, showing ion used).

and palaeo-depositional conditions of the likely source rock, and thermal maturation. In addition, the geo- chemical composition of the FI oil is compared with other samples from the same well (the RFT crude oil, 


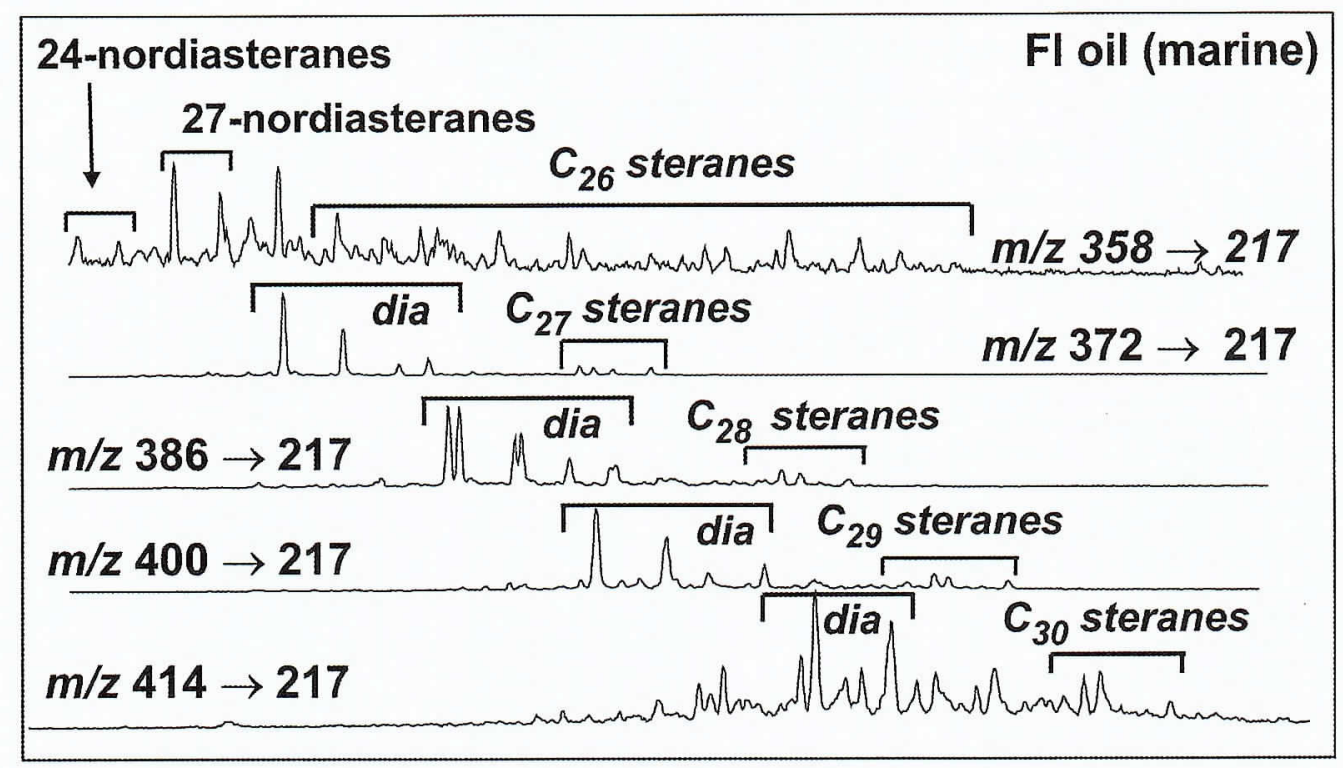

Figure 16 - MRM data for the FI oil, showing that diasteranes are more abundant than regular steranes at all carbon numbers. The presence of C30 steranes indicate a marine origin for the FI oil.

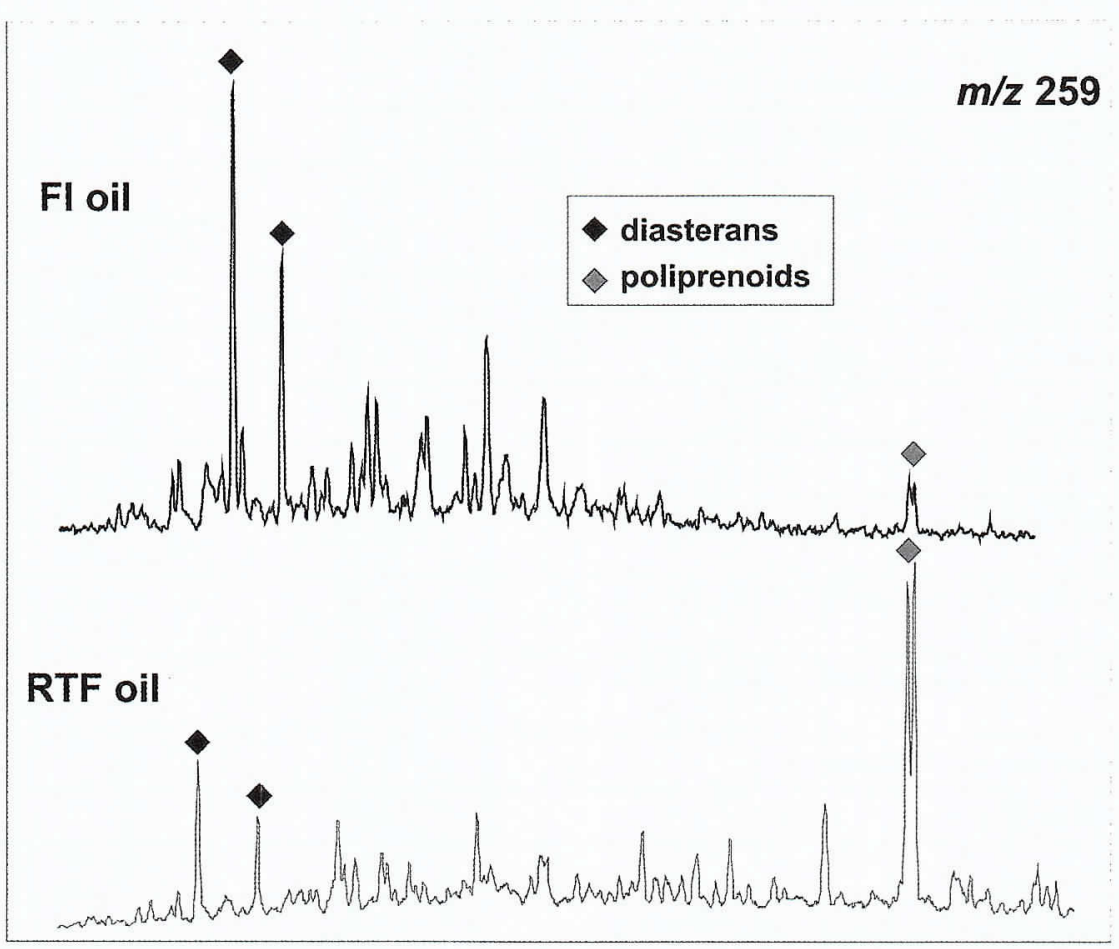

Figure 17 - Partial m/z 259 mass chromatograms of the FI oil and the RFT oil, showing the abundance of the tetracyclic polyprenoids Ta and $T b$ in relation to diasteranes. The FI oil has a more similar distribution to that of marine oils, whereas the RFT oil is more similar to lacustrine oils.

2 oil shows, and 13 mudstones) that were analyzed by geochemistry labs in Petrobras R\&D Center. This comparison is based on a number of parameters derived from the $n$-alkanes and branched/cyclic aliphatic hydrocarbons (Table $4 a$ and $b$ ).
Secondary alteration information There is no indication that the 5379-82 $\mathrm{m}$ FI oil sample has been affected by in-reservoir processes such as biodegradation, water washing or evaporative fractionation. $n$-Alkanes, alkylcyclohexanes and low molecular weight 
aromatic hydrocarbons are abundant in the FI oil, and there is no UCM hump, indicating that this sample is mostly unaffected by biodegradation. This is consistent with high abundances of low molecular weight $n$ alkanes and very low abundances of 25-norhopanes. In contrast, the $3069.5 \mathrm{~m}$ RFT oil has a prominent UCM hump and contains no detectable $n$-alkanes (Fig. 13). The isoprenoids $\mathrm{Pr}$ and $\mathrm{Ph}$ are present in reduced abundance, so this oil has been subjected to at least moderate biodegradation (Fig. 18).

The oil show from 4899-4908 $\mathrm{m}$ has experienced partial removal of $n$-alkanes and has a slight UCM hump, whereas the deeper oil show (5367-5379 m) from close to the location of the FI sample appears not to have been affected by biodegradation. This is shown by the variation in $\mathrm{Pr} / n-\mathrm{C}_{17}$ and $\mathrm{Ph} / n-\mathrm{C}_{18}$ ratios (Table 4a; Fig. 18). Mudstone samples from $5226-5709 \mathrm{~m}$ have quite variable isoprenoid/ $n$-alkane ratios (Fig. 18, Table 4b), which are most likely due to differences in thermal maturity, or possibly by impregnation of these fine-grained rocks with biodegraded oil. There are three possible explanations for the observed biodegradation differences within the sample set. Firstly, the lack of biodegradation of the FI oil could be due to its trapping in the mineral grains early during the charge history, prior to significant biodegradation occurring in the reservoir. This would explain why the crude oil and the shallower oil show are biodegraded, but does not explain why the deeper oil show is not biodegraded. Secondly, the lack of biodegradation of the FI oil and the deeper oil show may be because they are at a depth at which reservoir temperatures are above the threshold of $80^{\circ} \mathrm{C}$, that is the temperature that biodegradation does not normally occur in petroleum reservoirs (e.g. Connan, 1984; Larter et al., 2003). Thirdly, nutrient-rich meteoric water may not have invaded the deeper reservoir due to a lack of faults or other conduits, thus preventing bacterial growth that would cause biodegradation. The depth of these samples $(\sim 5370 \mathrm{~m})$ is consistent with the second possibility, as even a low geothermal gradient of $18^{\circ} \mathrm{C} / \mathrm{km}$ would suggest a reservoir temperature of $>100^{\circ} \mathrm{C}$. Crude oil from the current oil zone (3066-3069 $\mathrm{m})$ is likley reservoired at a lower temperature $\left(\sim 65^{\circ} \mathrm{C}\right)$, assuming the same geothermal gradient of $18^{\circ} \mathrm{C} / \mathrm{km}$. The shallower oil show at 4899-4908 m may be just on the boundary where some slight biodegradation can occur. Without bottom hole temperature and structural data, it is not possible to clarify these possibilities. The FI oil and deep oil show sample are very likely not biodegraded due to high reservoir temperature.

Source characterisation and correlation The 5379-5382 m FI oil sample was derived from a marine influenced source rock, based on the presence of $n$-propylcholestanes $\left(\mathrm{C}_{30}\right.$ steranes). There was a dominant marine algal contribution to the source rock, with limited terrestrial organic matter, based on the sterane and diasteranes distributions, which are all dominated by the $\mathrm{C}_{27}$ homologues, with similar and low amounts of $\mathrm{C}_{28}$ and $\mathrm{C}_{29}$ steranes (Fig. 16). There was some ter-

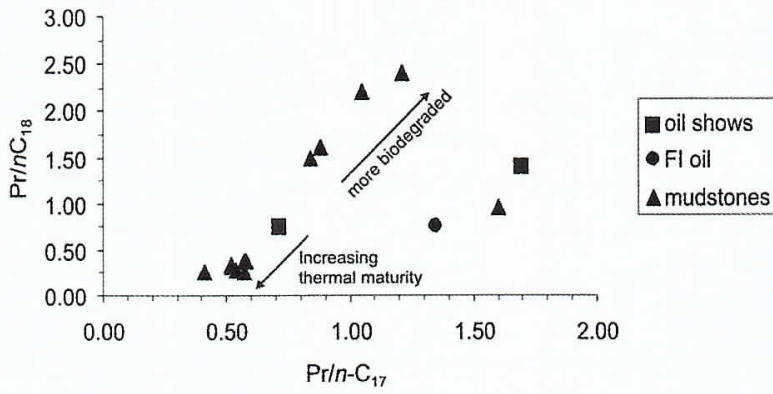

Figure 18 - Cross plot of $\mathrm{Pr} / \mathrm{n}$-C17 versus $\mathrm{Ph} / \mathrm{n}$ C18 for the samples from the well (see Table $4 a$ and $4 b$ for identity of samples).

restrial organic matter, as there is slight odd-over-even predominance in the $\mathrm{C}_{23+} n$-alkanes, but biomarkers (e.g. low $\mathrm{C}_{19}$ and $\mathrm{C}_{20}$ tricyclic terpanes, no oleanane or bicadinanes) show that this was minor. The $\mathrm{Pr} / \mathrm{Ph}$ ratio is consistent with deposition of organic matter under suboxic conditions (Didyk et al., 1978), and this is supported by the relatively high amount of extended tricyclic terpanes and the low content of 28,30-BNH (Table 2). The source rock was clay-rich, based on the abundance of rearranged terpanes (e.g. Ts, $\mathrm{C}_{29} \mathrm{Ts}$, diahopanes and the early eluting series) (Tables 2 and 3; Fig. 16). The low content of $29,30-\mathrm{BNH}$, the low relative amount of $\mathrm{C}_{29} \alpha \beta$ hopane (30-norhopane), the absence of detectable $\mathrm{C}_{30} 30$-norhopane and the low content of $2 \alpha$-methylhopanes provides no indication of a calcareous contribution to the source rock. The low $\mathrm{C}_{26} / \mathrm{C}_{25}$ and $\mathrm{C}_{21} / \mathrm{C}_{23}$ tricyclic terpane ratios (Fig. 7) are evidence against a lacustrine depositional environment for the source of the FI oil (Sofer, 1993; Schiefelbein et al., 1999). The relative abundance of the tetracyclic polyprenoids in the $5379-5382 \mathrm{~m} \mathrm{FI}$ oil is low (Tables 3 and 4; Fig. 17), and more similar to that of marine oils than lacustrine oils (cf. Schiefelbein et al., 1999). The age-specific information from the FI oil sample is based on $\mathrm{C}_{26}$ steranes, which suggest that it was derived from a Cretaceous source rock (Holba et al., 1998a, 1998b).

It is important to understand the composition of the $5379-5382 \mathrm{~m}$ FI oil with respect to other oils from the Campos Basin, and in particular the RFT crude oil, oil shows and mudstones from this well (Table $4 \mathrm{a}$ and $4 \mathrm{~b}$ ). The $\mathrm{C}_{26} / \mathrm{C}_{25}$ tricyclic terpane ratio of the RFT crude oil from $3069.5 \mathrm{~m}$ (1.42) is much higher than that of the FI oil (0.84; Fig. 14), and points to a lacustrine source rock for the RFT oil (Sofer, 1993). In effect, Schiefelbein et al., (1999) referred to most oils from the Campos Basin being lacustrine in nature. The two oil shows and all the mudstones (except one outlier, the shallowest sample; Table $4 \mathrm{~b}$ ) from the well do not have such high $\mathrm{C}_{26} / \mathrm{C}_{25}$ tricyclic terpane ratios as the crude oil, but fall within the somewhat equivocal range of 0.97-1.19, higher than the ratio of the FI oil. Based on this ratio and in the absence of $\mathrm{C}_{30}$ steranes, the RFT crude oil from $3069.5 \mathrm{~m}$ was generated from a lacustrine source rock which is not represented by 
Table 4a-Comparison of biodegradation, source and maturity parameters based on $n$-alkanes, branched and cyclic aliphatic hydrocarbons for the 5379-5382 m FI oil, the RFT crude oil, 2 oil shows and 13 mudstones. Note that values for the oil shows and mudstones were calculated based on peak heights supplied by Petrobras.

\begin{tabular}{|c|c|c|c|c|c|c|c|c|}
\hline Parameter & $\begin{array}{l}3069.5 \mathrm{~m} \\
\text { RFT oil }\end{array}$ & $\begin{array}{l}4899- \\
4908 \mathrm{~m} \\
\text { Oil } \\
\text { show }\end{array}$ & $\begin{array}{l}5367- \\
5379 \mathrm{~m} \\
\text { Oil } \\
\text { show }\end{array}$ & $\begin{array}{l}5379- \\
5382 \mathrm{~m} \\
\text { FI oil }\end{array}$ & $\begin{array}{c}5226- \\
5235 \mathrm{~m} \\
\text { Mudstone }\end{array}$ & $\begin{array}{c}5235- \\
5244 \mathrm{~m} \\
\text { Mudstone }\end{array}$ & $\begin{array}{c}5244- \\
5253 \mathrm{~m} \\
\text { Mudstone }\end{array}$ & $\begin{array}{c}5250- \\
5346 \mathrm{~m} \\
\text { Mudstone }\end{array}$ \\
\hline $\mathrm{Pr} / \mathrm{Ph}$ & 1.60 & 1.23 & 0.90 & 2.10 & 1.70 & 1.18 & 1.50 & 1.90 \\
\hline $\mathrm{Pr} / n-\mathrm{C}_{17}$ & 4.60 & 1.70 & 0.71 & 1.35 & 1.60 & 0.52 & 0.58 & 0.41 \\
\hline $\mathrm{Ph} / n-\mathrm{C}_{18}$ & 4.70 & 1.40 & 0.74 & 0.75 & 0.96 & 0.34 & 0.38 & 0.25 \\
\hline CPI-1 & n.d. & 1.16 & 1.07 & 1.06 & 1.09 & 1.05 & 0.82 & 1.06 \\
\hline $\mathrm{C}_{17} /\left(\mathrm{C}_{17}+\mathrm{C}_{27}\right)$ & n.d. & 0.69 & 0.65 & 0.81 & 0.50 & 0.64 & 0.72 & 0.82 \\
\hline $\mathrm{Ts} /(\mathrm{Ts}+\mathrm{Tm})$ & 0.47 & 0.54 & 0.77 & 0.76 & 0.27 & 0.61 & 0.46 & 0.54 \\
\hline $\mathrm{C}_{29} \mathrm{Ts} / \mathrm{C}_{29} \alpha \beta$ hopane & 0.45 & 0.44 & 1.20 & 1.16 & 0.55 & 0.57 & 0.44 & 0.55 \\
\hline $\mathrm{C}_{30} * / \mathrm{C}_{30} \alpha \beta$ hopane & 0.19 & 0.06 & 0.69 & 0.60 & 0.06 & 0.27 & 0.11 & 0.21 \\
\hline $\begin{array}{l}\mathrm{C}_{29} \alpha \beta \text { hopane/ } \\
\mathrm{C}_{30} \alpha \beta \text { hopane }\end{array}$ & 0.56 & 0.42 & 0.52 & 0.66 & 0.25 & 0.52 & 0.62 & 0.59 \\
\hline $\begin{array}{l}\text { Gammacerane/ } \\
\mathrm{C}_{30} \alpha \beta \text { Hopane }\end{array}$ & 0.31 & 0.49 & 0.16 & 0.17 & 0.21 & 0.09 & 0.04 & 0.07 \\
\hline $\mathrm{C}_{35} / \mathrm{C}_{34}$ homohopanes & 0.73 & 0.68 & 0.66 & 0.78 & 0.57 & 0.61 & 0.88 & 0.76 \\
\hline $\begin{array}{l}\mathrm{C}_{24} \text { tetracyclic/ } \mathrm{C}_{26} \text { tricyclic } \\
\text { terpanes }\end{array}$ & 0.14 & 0.56 & 0.72 & 0.37 & 0.90 & 1.16 & 1.5 & 0.84 \\
\hline $\mathrm{C}_{21} / \mathrm{C}_{23}$ tricyclic terpanes & 0.80 & 0.65 & 0.55 & 0.72 & 1.25 & 0.56 & 0.43 & 0.71 \\
\hline $\mathrm{C}_{26} / \mathrm{C}_{25}$ tricyclic terpanes & 1.42 & 0.97 & 1.08 & 0.84 & 1.70 & 1.11 & 1.12 & 1.10 \\
\hline $\begin{array}{l}\mathrm{C}_{24} \text { tetracyclic terpane/ } \\
\mathrm{C}_{30} \alpha \beta \text { hopane }\end{array}$ & 0.10 & 0.04 & 0.23 & 0.22 & n.d. & n.d. & n.d. & n.d. \\
\hline $\begin{array}{l}\mathrm{C}_{29} 25 \text {-norhopane/ } \\
\mathrm{C}_{30} \alpha \beta \text { hopane } \\
(\mathrm{m} / \mathrm{z} 177)\end{array}$ & 3.0 & n.d. & 1.08 & 1.10 & n.d. & 0.55 & 1.6 & 1.8 \\
\hline $\begin{array}{l}\mathrm{C}_{29} \alpha \alpha \alpha \text { steranes } \\
20 \mathrm{~S} /(20 \mathrm{~S}+20 \mathrm{R})\end{array}$ & 0.50 & 0.48 & 0.46 & 0.50 & n.d. & 0.48 & 0.44 & 0.40 \\
\hline $\begin{array}{l}\mathrm{C}_{29} \text { steranes } \\
\alpha \beta \beta /(\alpha \beta \beta+\alpha \alpha \alpha)\end{array}$ & 0.61 & 0.54 & 0.62 & 0.61 & 0.24 & 0.56 & 0.51 & 0.56 \\
\hline $\begin{array}{l}\% \mathrm{C}_{27} \alpha \beta \beta \text { steranes } 20 \mathrm{~S}+\mathrm{R}(\mathrm{m} / \mathrm{z} \\
218)\end{array}$ & 40.00 & 41.00 & 33.00 & 50.00 & 22.00 & 41.00 & 34.00 & 38.00 \\
\hline $\begin{array}{l}\% \mathrm{C}_{28} \alpha \beta \beta \text { steranes } 20 \mathrm{~S}+\mathrm{R}(\mathrm{m} / \mathrm{z} \\
218)\end{array}$ & 21.00 & 29.00 & 23.00 & 20.00 & 26.00 & 22.00 & 27.00 & 25.00 \\
\hline $\begin{array}{l}\% \mathrm{C}_{29} \alpha \beta \beta \text { steranes } 20 \mathrm{~S}+\mathrm{R}(\mathrm{m} / \mathrm{z} \\
218)\end{array}$ & 38.00 & 30.00 & 44.00 & 30.00 & 52.00 & 37.00 & 39.00 & 37.00 \\
\hline $\begin{array}{l}\mathrm{C}_{27} \beta \alpha \text { diasteranes } /(\alpha \alpha \alpha+\alpha \beta \beta \\
\text { steranes) }\end{array}$ & 0.52 & 1.28 & 4.50 & 4.10 & n.d. & 1.29 & 1.70 & 2.90 \\
\hline $\begin{array}{l}\text { TPP }(\mathrm{Ta}+\mathrm{Tb}) / \mathrm{C}_{27} \beta \alpha \text { diasteranes } \\
(m / z 259)\end{array}$ & 0.72 & 0.33 & 0.15 & 0.16 & 0.82 & 0.28 & 0.31 & 0.26 \\
\hline
\end{tabular}

any of the sampled mudstones from the same well, whereas the 5379-5382 $\mathrm{m}$ FI oil was derived from a marine shale, also not represented in the well. Other biomarker ratios for 5379-5382 $\mathrm{m}$ FI oil also enable a clear differentiation from the RFT $3069.5 \mathrm{~m}$ crude oil, including gammacerane/ $C_{30} \alpha \beta$ hopane, $C_{29} \alpha \beta$ hopane/ $\mathrm{C}_{30} \alpha \beta$ hopane, $\mathrm{C}_{30}$ diahopane $/ \mathrm{C}_{30} \alpha \beta$ hopane, $\mathrm{C}_{29} \mathrm{Ts} / \mathrm{C}_{29}$ $\alpha \beta$ hopane, Ts $/(\mathrm{Ts}+\mathrm{Tm}), \mathrm{C}_{27} \beta \alpha$ diasteranes $/(\alpha \alpha \alpha+\alpha \beta \beta$ steranes) and the TPP $(\mathrm{Ta}+\mathrm{Tb}) / \mathrm{C}_{27} \beta \alpha$ diasterane ratio (Tables 2 and 3). The high amount of gammacerane in the RFT oil is consistent with deposition of a lacustrine source rock in hypersaline and stratified water column conditions (Sinninghe et al., 1995).The sterane carbon number of the 5379-5382 $\mathrm{m}$ FI oil distribution is more $\mathrm{C}_{27}$ dominated than for any other samples from this well (Fig. 19), although this may have been contributed to by the higher thermal maturity of the FI oil (see below). The $\mathrm{Pr} / \mathrm{Ph}$ ratio of the $5379-5382 \mathrm{~m}$ FI oil (2.1) is higher than the $\mathrm{Pr} / \mathrm{Ph}$ ratios of the $3069.5 \mathrm{~m}$ crude oil and the five deepest mudstones (Table 4). These same five mudstone samples also have more $\mathrm{C}_{29}$ steranes than the other samples (Fig. 19), indicating some facies 
Table $4 b$ - Comparison of biodegradation, source and maturity parameters based on n-alkanes, branched and cyclic aliphatic hydrocarbons for the 5379-5382 m FI oil, the RFT crude oil, 2 oil shows and 13 mudstones. Note that values for the oil shows and mudstones were calculated based on peak heights supplied by Petrobras (continued).

\begin{tabular}{|c|c|c|c|c|c|c|c|c|}
\hline Parameter & $\begin{array}{c}5253- \\
5262 \mathrm{~m} \\
\text { Mudstone }\end{array}$ & $\begin{array}{l}5262- \\
5271 \mathrm{~m} \\
\text { Mudstone }\end{array}$ & $\begin{array}{c}5376- \\
5382 \mathrm{~m} \\
\text { Mudstone }\end{array}$ & $\begin{array}{c}5382- \\
5400 \mathrm{~m} \\
\text { Mudstone }\end{array}$ & $\begin{array}{c}5619- \\
5637 \mathrm{~m} \\
\text { Mudstone }\end{array}$ & $\begin{array}{c}5637- \\
5655 \mathrm{~m} \\
\text { Mudstone }\end{array}$ & $\begin{array}{c}5655- \\
5664 \mathrm{~m} \\
\text { Mudstone }\end{array}$ & $\begin{array}{c}5673- \\
5691 \mathrm{~m} \\
\text { Mudstone }\end{array}$ \\
\hline $\mathrm{Pr} / \mathrm{Ph}$ & 2.20 & 2.00 & 1.50 & 1.34 & 0.32 & 0.31 & 0.45 & 0.44 \\
\hline $\mathrm{Pr} / n-\mathrm{C}_{17}$ & 0.57 & 0.54 & 0.52 & 0.57 & 1.21 & 1.05 & 0.88 & 0.84 \\
\hline $\mathrm{Ph} / n-\mathrm{C}_{18}$ & 0.25 & 0.28 & 0.32 & 0.38 & 2.40 & 2.20 & 1.60 & 1.50 \\
\hline CPI-1 & 1.09 & 1.09 & 1.05 & 1.03 & 0.78 & 0.89 & 0.94 & 0.96 \\
\hline $\mathrm{C}_{17} /\left(\mathrm{C}_{17}+\mathrm{C}_{27}\right)$ & 0.70 & 0.72 & 0.64 & 0.63 & 0.67 & 0.61 & 0.70 & 0.48 \\
\hline $\mathrm{Ts} /(\mathrm{Ts}+\mathrm{Tm})$ & 0.48 & 0.48 & 0.61 & 0.69 & 0.81 & 0.76 & 0.76 & 0.71 \\
\hline $\mathrm{C}_{29} \mathrm{Ts} / \mathrm{C}_{29} \alpha \beta$ hopane & 0.45 & 0.44 & 0.40 & 0.92 & 0.97 & 0.79 & 0.81 & 0.60 \\
\hline $\mathrm{C}_{30} * / \mathrm{C}_{30} \alpha \beta$ hopane & 0.14 & 0.14 & 0.24 & 0.45 & 0.36 & 0.32 & 0.50 & 0.37 \\
\hline $\begin{array}{l}C_{29} \alpha \beta \text { hopane/ } \\
C_{30} \alpha \beta \text { hopane }\end{array}$ & 0.67 & 0.68 & 0.79 & 0.54 & 0.66 & 0.71 & 0.71 & 0.76 \\
\hline $\begin{array}{l}\text { Gammacerane/ } \\
\mathrm{C}_{30} \alpha \beta \text { Hopane }\end{array}$ & 0.05 & 0.06 & 0.12 & 0.09 & 0.52 & 0.40 & 0.36 & 0.23 \\
\hline $\mathrm{C}_{35} / \mathrm{C}_{34}$ homohopanes & 0.85 & 0.84 & 0.85 & 0.68 & 1.40 & 1.34 & 1.50 & 1.50 \\
\hline $\begin{array}{l}\mathrm{C}_{24} \text { tetracyclic/ } \mathrm{C}_{26} \text { tricyclic } \\
\text { terpanes }\end{array}$ & 1.33 & 1.23 & 0.98 & 0.77 & 0.74 & 0.68 & 0.44 & 0.39 \\
\hline $\mathrm{C}_{21} / \mathrm{C}_{23}$ tricyclic terpanes & 0.53 & 0.56 & 0.71 & 0.64 & 0.58 & 0.63 & 0.65 & 0.52 \\
\hline $\mathrm{C}_{26} / \mathrm{C}_{25}$ tricyclic terpanes & 1.10 & 1.12 & 1.17 & 1.06 & 1.18 & 1.12 & 1.19 & 1.17 \\
\hline $\begin{array}{l}\mathrm{C}_{24} \text { tetracyclic terpane/ } \\
\mathrm{C}_{30} \alpha \beta \text { hopane }\end{array}$ & n.d. & n.d. & n.d. & n.d. & n.d. & n.d. & n.d. & n.d. \\
\hline $\begin{array}{l}\mathrm{C}_{29} 25 \text {-norhopane/ } \\
\mathrm{C}_{30} \alpha \beta \text { hopane } \\
(\mathrm{m} / \mathrm{z} 177)\end{array}$ & 1.70 & 1.50 & 0.39 & 1.40 & 1.26 & 1.40 & 1.90 & 1.90 \\
\hline $\begin{array}{l}\mathrm{C}_{29} \alpha \alpha \alpha \text { steranes } \\
20 \mathrm{~S} /(20 \mathrm{~S}+20 \mathrm{R})\end{array}$ & 0.44 & 0.43 & 0.43 & 0.44 & 0.42 & 0.41 & 0.41 & 0.43 \\
\hline $\begin{array}{l}\mathrm{C}_{29} \text { steranes } \\
\alpha \beta \beta /(\alpha \beta \beta+\alpha \alpha \alpha)\end{array}$ & 0.53 & 0.53 & 0.60 & 0.59 & 0.63 & 0.64 & 0.64 & 0.64 \\
\hline $\begin{array}{l}\% \mathrm{C}_{27} \alpha \beta \beta \text { steranes } 20 \mathrm{~S}+\mathrm{R} \\
(\mathrm{m} / \mathrm{z} 218)\end{array}$ & 35.00 & 35.00 & 40.00 & 40.00 & 11.70 & 12.90 & 13.20 & 14.90 \\
\hline $\begin{array}{l}\% \mathrm{C}_{28} \alpha \beta \beta \text { steranes } 20 \mathrm{~S}+\mathrm{R} \\
(\mathrm{m} / \mathrm{z} 218)\end{array}$ & 27.00 & 26.00 & 23.00 & 25.00 & 23.00 & 21.00 & 21.00 & 22.00 \\
\hline $\begin{array}{l}\% \mathrm{C}_{29} \alpha \beta \beta \text { steranes } 20 \mathrm{~S}+\mathrm{R} \\
(\mathrm{m} / \mathrm{z} 218)\end{array}$ & 38.00 & 39.00 & 37.00 & 35.00 & 66.00 & 66.00 & 66.00 & 63.00 \\
\hline $\begin{array}{l}\mathrm{C}_{27} \beta \alpha \text { diasteranes } / \\
(\alpha \alpha \alpha+\alpha \beta \beta \text { steranes })\end{array}$ & 1.70 & 1.50 & 3.00 & 4.60 & 1.31 & 1.29 & 1.60 & 1.40 \\
\hline $\begin{array}{l}\mathrm{TPP}(\mathrm{Ta}+\mathrm{Tb}) / \mathrm{C}_{27} \beta \alpha \\
\text { diasteranes }(m / z 259) \\
\end{array}$ & 0.32 & 0.35 & 0.22 & 0.16 & 0.12 & 0.12 & 0.20 & 0.22 \\
\hline
\end{tabular}

differentiation. The shallower oil show (4899-4908 m) has several biomarker similarities to the $3069.5 \mathrm{~m}$ RFT crude oil, whereas the deeper oil show (5367-5379 m) has several biomarker similarities to the $5379-5382 \mathrm{~m}$ FI oil (Table 4a).

In summary, the biomarker data indicate that the 5379-5382 m FI oil was generated from a Cretaceous marine shale, not represented by any of the fine-grained samples in this well. This source rock with clay-rich and carbonate-poor, and was deposited in a suboxic environment with only limited terrestrial organic matter input. The shallower crude oil from $3069.5 \mathrm{~m}$ was generated by a different lacustrine facies.

Thermal maturity The $5379-5382 \mathrm{~m}$ FI oil is characterized by significant consistency in many thermal maturity parameters across most compound groups and molecular weight ranges. These predominantly indicate a maturity equivalent to the peak of oil window for the FI oil. This consistency indicates it most likely represents a single oil charge, and not a mixture. The tricyclic terpanes are abundant relative to hopanes, 


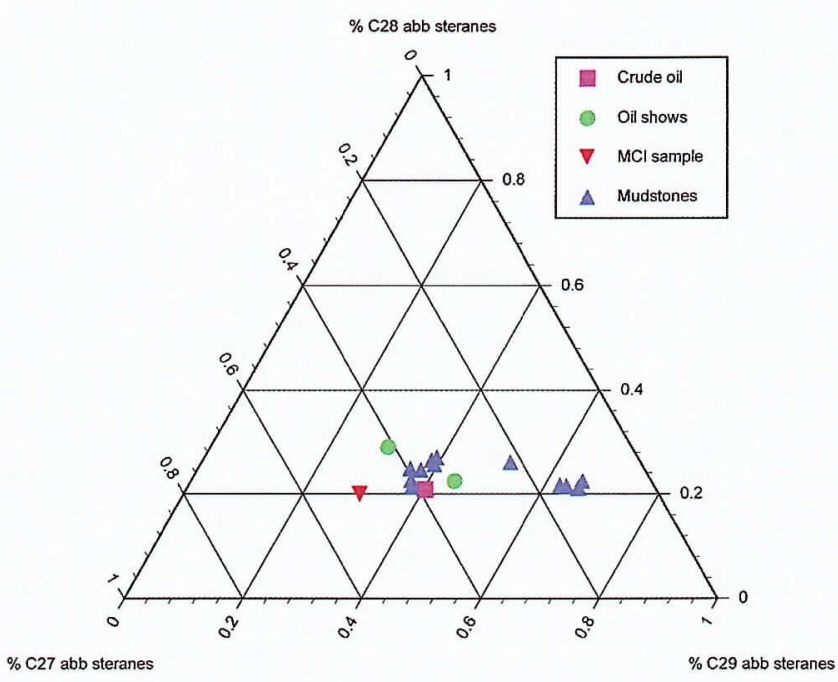

Figure 19 - Ternary plot of C27:C28:C29 $\alpha \beta \beta$ steranes $20 S+R$ (see Table 4 for identity of the samples). Data is based on $\mathrm{m} / \mathrm{z} 218$ values. Note that values for the crude oil, oil shows and mudstones were calculated based on peak heights supplied by Petrobras.

suggesting moderate to high thermal maturity. Hopane $\alpha \beta /(\alpha \beta+\beta \alpha)$ thermal maturity ratios are at equilibrium, suggesting the sample has reached at least $0.7 \%$ VRE, whereas the Ts/Tm ratio and the overall abundances of rearranged hopanes are consistent with a higher thermal maturity in the peak oil window maturity. The sterane $\mathrm{C}_{29}$ sterane $\alpha \alpha \alpha$ 20S/20R ratio (Sofer et al., 1993) and the $C_{29} \alpha \beta \beta /(\alpha \beta \beta+\alpha \alpha \alpha)$ sterane are consistent with a maturity of around $0.8 \%-0.9 \%$ VRE. The $\mathrm{Pr} / n-\mathrm{C} 17$ and $\mathrm{Ph} / n$-C18 ratios suggest a maturity level within the early oil generation window, assuming that the FI oil is not biodegraded, as appears likely. Compared to the $3069.5 \mathrm{~m}$ RFT crude oil, the shallower oil show (4899$4908 \mathrm{~m}$ ) and the mudstones, the $5379-5382 \mathrm{~m} \mathrm{FI}$ oil is more thermally mature, based on $\mathrm{C}_{30}$ diahopane/ $\mathrm{C}_{30}$ $\alpha \beta$ hopane, $\mathrm{C}_{29} \mathrm{Ts} / \mathrm{C} 29 \alpha \beta$ hopane, $\mathrm{Ts} /(\mathrm{Ts}+\mathrm{Tm}), \mathrm{C}_{27} \beta \alpha$ diasteranes/( $\alpha \alpha \alpha+\alpha \beta \beta$ steranes $)$ and $\mathrm{C}_{29} \alpha \beta \beta /(\alpha \beta \beta+\alpha \alpha \alpha)$ steranes (Table 4). The crude oil has a higher $\mathrm{C}_{29} \alpha \alpha \alpha$ $20 S /(20 S+20 R)$ sterane ratio than any of the other samples, but this is likley anomalous and may relate to alteration of the steranes in this sample by biodegradation. The 5379-5382 m FI oil has similar thermal maturities to the deeper oil show (5367-5379 m - (Table 4a).

In summary, the $5379-5382 \mathrm{~m}$ FI oil is interpreted to be a single fluid which was generated in the peak oil window. It is a more mature fluid than the $3069.5 \mathrm{~m}$ RFT crude oil. The 5379-5382 m FI oil could not have been generated from the mudstone samples (5226-5709 m), as these have lower thermal maturities. Consequently, generation from more mature source rocks, possibly from the same stratigraphic horizon as the intersected mudstones but buried more deeply, or from a different source unit charging vertically is inferred.
CONCLUSIONS

Quality of the MCI data (1) The amount of oil recovered from inclusions in the $5379-5382 \mathrm{~m}$ palaeo-oil zone sample was significantly higher the system blank and lower than rinse blank for all monitored compound classes, giving very high confidence in the integrity of the data; (2) Good quality data was acquired using the off-line MCI methods for the 5379-5382 m FI oil sample, and relates to oil inclusions trapped in both quartz and feldspar grains. There were too few oil inclusions with too small a size to enable successful MCI analysis of the oil zone sample (3066-3069 m).

Secondary alteration (3) There is no indication that the 5379-5382 m FI oil sample was affected by in-reservoir processes such as biodegradation or water washing; (4) Shallower crude oil from the RFT (3069.5 $\mathrm{m}$ ) and an oil show (4899-4908 m) are biodegraded, so the lack of biodegradation in the FI oil and the deeper oil show (5367-5379 m) may be either due to reservoir temperatures being above the threshold of $80^{\circ} \mathrm{C}$, or due to a lack of faults for invasion of nutrient-rich meteoric water required for bacterial growth.

Source characterisation and correlation (5) The FI oil was generated by a Cretaceous marine or marine influenced shale. This clay-rich source rock, was deposited in a suboxic environment with only limited terrestrial organic matter input; (6) The low $\mathrm{C}_{26} / \mathrm{C}_{25}$ and $\mathrm{C}_{21} / \mathrm{C}_{23}$ tricyclic terpane ratios of the $\mathrm{FI}$ oil are evidence against a lacustrine depositional environment, and the relative abundance of the tetracyclic polyprenoids is more similar to that of marine oils than lacustrine oils; (7) The nordiacholestane and norcholestane ratios for the FI oil suggest that it was derived from a Cretaceous source rock; (8) The 5379-5382 m FI does not correlate well with the shallower RFT oil and oil show (4899-4908 m), which may have been generated from a lacustrine source rock which is not represented by any of the sampled mudstones from the same well; (9) The deeper oil show (5367-5379 m) has several biomarker similarities to the 5379-5382 m FI oil; (10) The 5379$5382 \mathrm{~m}$ FI does not correlate well with any of the finegrained samples in the well.

Thermal maturity (11) The FI oil is characterised by significant consistency in many thermal maturity parameters across most compound groups and molecular weight ranges. These predominantly indicate a peak oil window maturity for the FI oil (VRE $=0.8-0.9 \%$ ). This consistency indicates it most likely represents a single oil charge, and not a mixture; (12) The FI oil is a more mature fluid than the RFT crude oil, but has a similar thermal maturity to the deeper oil show (5367$5379 \mathrm{~m}$ ); (13) The 5379-5382 m FI oil could not have been generated from the mudstone samples in the well (5226-5691 m), as these have lower thermal maturities. Consequently, generation from a deeper source and vertical migration is inferred. 
Acknowledgements We thank Manzur Ahmed and Robinson Quezada for analytical assistance with the fluid inclusion analysis. We would like to thank Petro- bras for the permission to publish this paper and to Dr. Eugenio Vaz dos Santos Neto for the critical review.

\section{References}

Connan J. 1984. Biodegradation of crude oils in reservoirs. In: Brooks J. \& Welte D.H (eds.) Advances in Petroleum Geochemistry. London, Academic Press, v.1, p. 229335.

Didyk B.M., Simoneit B.R.T., Brassell S.C., Eglinton G. 1978. Organic geochemical indicators of palaeoenvironmental conditions of organic sedimentation. Nature, 272:216222.

Eadington P.J., Lisk M., Krieger F.W. 1996. Identifying oil well sites. United States Patent No. 5,543,616.

England W.A., Mackenzie A.S., Mann D.M., Quigley T.M. 1987. The movement and entrapment of petroleum fluids in the subsurface. Journal of the Geological Society of London, 144:327-347.

George S.C., Lisk M., Eadington P.J., Quezada R.A. 1998. Geochemistry of a palaeo-oil column: Octavius 2, Vulcan Sub-basin, in The Sedimentary Basins of Western Australia 2. In: Purcell P.G. \& Purcell R.R. (eds) Petroleum Exploration Society of Australia Symposium, Perth, WA, p. 195-210.

George S.C., Volk H., Ruble T.E., Lisk M., Ahmed M., Liu K., Quezada R.A., Dutkiewicz A., Brincat M., Smart S., Horsfield B. 2001. Extracting oil from fluid inclusions for geochemical analyses: Size matters! In: International Meeting on Organic Geochemistry, 20 ${ }^{\text {th }}$. EAOG, Nancy, Abstract Book, v. 1, p. 467-468.

George S.C., Lisk M., Eadington P.J. 2004. Fluid inclusion evidence for an early, marine-sourced oil charge prior to gas-condensate migration, Bayu-1, Timor Sea, Australia. Marine and Petroleum Geology, 21:1107-1128.

George S.C., Volk H., Ahmed M. 2007. Geochemical analysis techniques and geological applications of oil-bearing fluid inclusions, with some Australian case studies. Journal of Petroleum Science and Engineering , 57:119138.

Guardado L.R., Spadini A.R., Brandão J.S.L., Mello M.R. 2000. Petroleum system of the Campos Basin. In: Mello M.R. \& Katz B.J. (eds.) Petroleum systems of South Atlantic margins. AAPG Memoir 73:317-324.'

Holba A.G., Dzou L.I.P., Masterson W.D., Hughes W.B., Huizinga B.J., Singletary M.S., Moldowan J.M., Mello M.R., Tegelaar E. 1998a. Application of 24norcholestanes for constraining source age of petroleum. Organic Geochemistry, 29:1269-1283.

Holba A.G., Tegelaar E.W., Huizinga B.J., Moldowan J.M., Singletary M.S., McCaffrey M.A., Dzou L.I.P. 1998b. 24-Norcholestanes as age-sensitive molecular fossils. Geology, 26:783-786.

Holba A.G., Tegelaar E., Ellis L., Singletary M.S., Albrecht P. 2000. Tetracyclic polyprenoids: indicators of freshwater (lacustrine) algal input. Geology, 28:251-254.

Holba A.G., Ellis L., Dzou L.I.P., Hallam A., Masterson W.E., Francu J., Fincannon A.L. 2001. Extended tricyclic terpanes as age discriminators between Triassic, Early Jurassic and Middle-Late Jurassic oils. In: of the International Meeting on Organic Geochemistry, $20^{\text {th }}$, Nancy, France, Abstracts, P/TUE1/35, p. 464.

Holba A.G., Zumberge J., Huizinga B.J., Rosenstein H., Dzou L.I.P. 2003. Extended tricyclic terpanes as indicators of marine upwelling. In: International Meeting on Organic Geochemistry, 21 $1^{\text {st }}$, EAOG, Kraków, Book of Abstracts, Part I, p. 131.

Larter S., Wilhelms A., Head I., Koopmans M., Aplin A., Di Primio R., Zwach C., Erdmann M., Telnaes N. 2003. The controls on the composition of biodegraded oils in the deep subsurface - Part 1: biodegradation rates in petroleum reservoirs. Organic Geochemistry, 34:601613.

Laubach S.E. 1997. A method to detect natural fracture strike in sandstones, AAPG Bulletin, 81(4):604-623.

Lisk M. \& Eadington P.J. 1994. Oil migration in the Cartier Trough, Vulcan Sub-basin. In: Purcell P.G. \& Purcell R.R. (eds.) The Sedimentary Basins of Western Australia. Proceedings of the Petroleum Exploration Society of Australia, Perth, WA, p. 301-312.

Lisk M., Ostby J., Russel N.J., O'Brien G.W. 2000. Oil migration history of the offshore Canning Basin, Australian Petroleum Production and Exploration Association Journal, 40:133-151.

Lisk M., O'Brien G.W., Eadington P.J. 2002. Quantitative evaluation of the oil-leg potential in the Oliver gas field, Timor Sea, Australia. American Association of Petroleum Geologists Bulletin, 86:1531-1542.

Liu K., Eadington P.J., Kennard J.M., Middleton H.A., George S.C., Ahmed M., Cope P. 2004. Oil migration in the Vulcan Sub-basin, Timor Sea, investigated using GOI and FIS Data. In: Ellis G. K., Baillie P.W., Munson T.J. (eds.) Timor Sea Petroleum Geoscience, Timor Sea Symposium, Darwin, Northern Territory, Northern Territory Geological Survey, Special Publication 1, p. 333-351.

Mackenzie A.S., Patience R.L., Maxwell J.R., Vandenbroucke M., Durand B. 1980. Molecular parameters of maturation in the Toarcian shales, Paris Basin, France I. Changes in the configuration of acyclic isoprenoid alkanes, steranes and triterpanes. Geochimica et Cosmochimica Acta, 44:1709-1721.

Mackenzie A.S. (1984) Applications of biological markers in petroleum geochemistry. In: Brooks J.M. \& Welte D.H. (eds.) Advances in Petroleum Geochemistry 1. London, Academic Press, p.115-212.

Milani E.J., Brandão J.A.S.L., Zalán P.V., Gamboa L.A.P. 2000. Petróleo na Margem Continental Brasileira : Geologia, Exploração, Resultaods e Pespectivas. Brazilian Journal of Geophysics, 18(3):351-396.

Moldowan J.M., Fago F.J., Lee C.Y., Jacobson S.R., Watt 
D.S., Slougui N.E., Jeganathan A., Young D.C. 1990. Sedimentary 24-n-propylcholestanes, molecular fossils diagnostic for marine algae. Science, 247:309-312.

Moldowan J.M., Fago F.J., Carlson R.M.K., Young D.C., Van Duyne G., Clardy J., Schoell M., Pillinger C.T., Watt D.S. 1991. Rearranged hopanes in sediments and petroleum. Geochimica et Cosmochimica Acta, 55:3333-3353.

Nytoft H.P. 2007. Novel "isohopanes" and their use as source markers. In: European Association of Organic Geochemists, International Meeting on Organic Geochemistry, 23, Torquay, England, Book of Abstracts, 273-274.

Oxtoby N.H., Mitchell A.W., Gluyas J.G. 1995. The filling and emptying of the Ula Oilfield: fluid inclusion constraints. In: Cubitt J.M. \& England W.A. (eds) The Geochemistry of Reservoirs. Geological Society Special Publication v.86, p. 141-157.

Pettijohn F.J., Potter P.E., Siever R. 1972. Sand and Sandstone. New York, Springer-Verlag, 618p.

Powers M.C. (1953) A new roundness scale for sedimentary particles. Journal of Sedimentary Petrology, 23:117119.

Schiefelbein C.F., Zumberge J.E., Cameron N.R., Brown S.W. 1999. Petroleum systems in the South Atlantic margins. In: Cameron N.R., Brooks JM., Bernard B.B., Zumberge J.E., Brown S. (eds.) The oil and gas habitats of the South Atlantic. Geological Society, London, Special Publications., v.153, p.169-179.

Seifert W.K. \& Moldowan, J.M. 1986. Use of biological markers in petroleum exploration. In: Johns R.B. (ed.) Methods in geochemistry and geophysics. Amsterdam, Elsevier, v. 24, p. 261-290.

Sinninghe Damsté J.S., Kenig F., Koopmans M.P., Köster
J., Schouten S., Hayes J.M., de Leeuw J.W. (1995) Evidence for gammacerane as an indicator of water column stratification. Geochimica et Cosmochimica Acta 59:1895-1900.

Sofer Z. 1993. Distribution of genetic oil families in West Africa based on biomarker ratios. In: Latin American Congress on Organic Geochemistry, $3^{\text {rd }}$, Manaus, Brazil, Extended abstracts, p. 134-137.

Summons R.E. \& Jahnke L.L. 1990. Identification of the methylhopanes in sediments and petroleum. Geochimica et Cosmochimica Acta 54:247-251.

Telnaes N., Isaksen G.H., Farrimond P. 1992. Unusual triterpane distributions in lacustrine oils. Organic Geochemistry, 18:785-789.

Volk H., George S.C., Middleton H., Schofield S. 2005. Geochemical comparison of fluid inclusion and reservoired oils in the Papuan Foreland - evidence for previously unrecognised petroleum source rocks. Organic Geochemistry, 36:29-51.

Volk H., Horsfield B., Mann U., Suchý V. 2002. Variability of petroleum inclusions in vein, fossil and vug cements - a geochemical study in the Barrandian Basin (Lower Palaeozoic, Czech Republic). Organic Geochemistry, 33:1319-1341.

Volkman J.K., Alexander R., Kagi R.I., Woodhouse G.W. 1983. Demethylated hopanes in crude oils and their applications in petroleum geochemistry. Geochimica et Cosmochimica Acta, 47:785-794.

Manuscrito BR 02

Submetido em 19 de dezembro de 2007 Aceito em 10 de março de 2008 